2011

\title{
Ten Years After: Bartnicki v. Vopper as Laboratory for First Amendment Advocacy and Analysis
}

Eric Easton

University of Baltimore School of Law, eeaston@ubalt.edu

Follow this and additional works at: http://scholarworks.law.ubalt.edu/all_fac

Part of the First Amendment Commons, Privacy Law Commons, and the Supreme Court of the United States Commons

\section{Recommended Citation}

Ten Years After: Bartnicki v. Vopper as Laboratory for First Amendment Advocacy and Analysis, 50 U. Louisville L. Rev. 287 (2011)

This Article is brought to you for free and open access by the Faculty Scholarship at ScholarWorks@University of Baltimore School of Law. It has been accepted for inclusion in All Faculty Scholarship by an authorized administrator of ScholarWorks@University of Baltimore School of Law. For more information, please contact snolan@ubalt.edu. 


\title{
TEN YEARS AFTER: BARTNICKI $V$. VOPPER AS A LABORATORY FOR FIRST AMENDMENT ADVOCACY AND ANALYSIS
}

\author{
Eric B. Easton
}

\section{INTRODUCTION}

How many ways can one approach a First Amendment analysis? What influences a lawyer or a judge to select one analytical approach over another? And what is the long-term effect of a court's choice of one over another? In Bartnicki v. Vopper, ${ }^{1}$ a 2001 case in which the U.S. Supreme Court considered federal and state statutes prohibiting the disclosure of illegally intercepted telephone conversations, ${ }^{2}$ we are privileged to have a small laboratory through which to study the first two questions. And, from the vantage point of ten years, we ought to be able to make some informed predictions as to the third.

In Bartnicki, the U.S. Supreme Court held that the First Amendment gave the news media a right to publish truthful information on matters of public concern, even if unlawfully acquired, provided the publisher did not participate in the unlawful conduct. ${ }^{3}$ How the Court ultimately reached that conclusion is one principal focus of this Article, precisely because the story of this litigation reveals so much about alternative First Amendment analyses and the process of influencing the courts' choices among them.

In this one case, the district court framed the issue as a battle between conflicting and potentially controlling precedents. ${ }^{4}$ The circuit court

- Eric B. Easton is Professor of Law at the University of Baltimore School of Law.

I 532 U.S. 514 (2001).

2 See Omnibus Crime Control and Safe Streets Act of 1968, 18 U.S.C. § 2511(1) (2010) ("Except as otherwise specifically provided in this chapter, any person who ... (c) intentionally discloses, or endeavors to disclose, to any other person the contents of any wire, oral, or electronic communication, knowing or having reason to know that the information was obtained through the interception of a wire, oral, or electronic communication in violation of this subsection . . shall be punished . . . ."); Pennsylvania Wiretapping and Electronic Surveillance Control Act, 18 PA. Cons. STAT. § 5703 (2010) ("Except as otherwise provided in this chapter, a person is guilty of a felony of the third degree if he ... (2) intentionally discloses or endeavors to disclose to any other person the contents of any wire, electronic or oral communication, or evidence derived therefrom, knowing or having reason to know that the information was obtained through the interception of a wire, electronic or oral communication ....").

${ }^{3}$ Bartnicki, 532 U.S. at 535 ("[A] stranger's illegal conduct does not suffice to remove the First Amendment shield from speech about a matter of public concern.").

${ }^{4}$ See infra Part III. 
selected a doctrinal formula called "intermediate scrutiny" and applied it in textbook fashion to reach its conclusion. ${ }^{5}$ And the U.S. Supreme Court resorted to an "ad hoc balancing" of interests in personal privacy versus publicly significant information, ultimately ruling in favor of the latter. ${ }^{6}$

Even more interesting are the reasons why the courts made the decisions they did. Did they track the arguments of the party litigants? How influential was the U.S. government's intervention to defend the federal statute at issue? And what role did the media defense bar play? Bartnicki provides an excellent opportunity to study the press's increasing sophistication in helping to shape First Amendment doctrine through litigation in the Supreme Court. ${ }^{7}$

Some seventy years earlier, the press's first serious effort in Near $v$. Minnesota ${ }^{8}$ established the supremacy of the right to publish. ${ }^{9}$ Forty years later, the disastrous decision in Branzburg v. Hayes ${ }^{10}$ stunted any First Amendment right to gather news and revealed the need for coordinated media attention to doctrinal litigation. ${ }^{11}$ Now, after another thirty years, the Bartnicki case brought publishing and newsgathering issues together, and this time the press proved to be up to the challenge.

As interesting as this case may be from analytical and strategic perspectives, the implications of Bartnicki's contribution to First Amendment doctrine are difficult to discern. The Court allowed a lawabiding press to publish with impunity truthful, important information, regardless of its initial unlawful acquisition, but did it significantly expand the public's right to receive newsworthy information?

The question actually presented by this case was whether the broadcaster could, consistent with the First Amendment, be punished for his dissemination of publicly significant information initially acquired from an unknown person who had illegally intercepted a private telephone conversation. ${ }^{12}$ Both federal and state statutes provided a civil cause of

5 See infra Part IV.

6 See infra Part VI.

7 This is the fourth in a series of articles on the subject of the press as a constitutional litigator, beginning with Eric B. Easton, The Press as an Interest Group: Mainstream Media in the United States Supreme Court, 14 UCLA ENT. L. REV. 247 (2007) [hereinafter Interest Group] and including Eric B. Easton, The Colonel's Finest Campaign: Robert R. McCormick and Near v. Minnesota, 60 FED. CoMM. L.J. 183 (2008) [hereinafter McCormick] and Eric B. Easton, A House Divided: Earl Caldwell, the New York Times, and the Quest for a Testimonial Privilege, 2009 UTAH L. REV: 1293 [hereinafter Caldwell].

8283 U.S. 697 (1931).

9 See McCormick, supra note 7, at 223.

10408 U.S. 665 (1972).

1t See Caldwell, supra note 7, at 1294.

12 Bartnicki v. Vopper, 532 U.S. 514, 524-25 (2001). 
action for not only the interception, but also the further disclosure of the intercepted conversation. ${ }^{13}$

In declaring the disclosure provision unconstitutional as applied, however, the Court declined to abstract its holding to a legal principle. The ambiguity of the decision suggests that a different balance could be struck if the subject matter of the disclosure were, say, national security rather than labor relations matters. The conclusion of this Article looks to the contemporary WikiLeaks.com controversy to illuminate this issue ${ }^{14}$

Part II of this Article recounts the underlying facts of the Bartnicki case and its procedural posture up to certiorari. Part III examines the two contending precedents initially asserted by the parties and accepted as the basis for analysis in the district court. Part IV looks at the shift to doctrinal analysis in the court of appeals, prompted at least in part by the federal government's entry into the case. Part V studies the proceedings before the U.S. Supreme Court, with emphasis on the participation and analytical approach of prominent media lawyers. Part VI dissects the opinion and the shift to an ad hoc balancing approach, particularly in light of the press arguments, while Part VII ventures some predictions about the significance of the decision with the WikiLeaks.com controversy as a backdrop.

\section{II. "BLOW OFF THEIR FRONT PORCHES”?}

The Wyoming Valley of Pennsylvania encompasses the cities of Scranton, Pittston, and Wilkes-Barre, and numerous smaller towns, including the boroughs of Courtdale, Edwardsville, Forty Fort, Larksville, Luzerne, Plymouth, Pringle, Kingston, and Swoyersville. ${ }^{15}$ These towns, all by Interstate Highway 81 and just a little northwest of Wilkes-Barre, are served by the Wyoming Valley West School District. ${ }^{16}$ The district boasts seven elementary schools, a middle school, and a high school, with about 5,000 students altogether. ${ }^{17}$

13 See 18 U.S.C. $\$ 2520$ (a) (2010) ("[A]ny person whose wire, oral, or electronic communication is intercepted, disclosed, or intentionally used in violation of this chapter may in a civil action recover from the person or entity, other than the United States, which engaged in that violation such relief as may be appropriate."); 18 PA. CONS. STAT. $§ 5725(a)$ (2010) ("Any person whose wire, electronic or oral communication is intercepted, disclosed or used in violation of this chapter shall have a civil cause of action against any person who intercepts, discloses or uses or procures any other person to intercept, disclose or use, such communication .....").

14 See Wikileaks, THE HuFFINGTON POST, http:/www.huffingtonpost.com/news/wikileaks (last visited Nov. 23, 2011).

is Wyoming Valley West School District, WIKIPED1A, http://en.wikipedia.org/wiki/Wyoming Valley_West_School_District (last modified Oct. 14, 2011).

${ }_{16}$ Id.

$17 \mathrm{Id}$. 
From mid-1992 until November 1993, the district was torn by a contract dispute between the Wyoming Valley West School Board and the Wyoming Valley West Education Association, the union representing the district's 341 teachers. ${ }^{18}$ Five months of hard bargaining for a new teachers' contract turned nasty in October 1992, when the board decided to warn teachers that they might be subject to furlough a week before the next scheduled bargaining session. ${ }^{19}$ By March 1993, the teachers had halted all volunteer work, including chaperoning school activities, ${ }^{20}$ and in May the union threatened to strike in early June unless their salary demands were met. $^{21}$

The union was asking for six percent increases each year for the next three years, raising the average salary from $\$ 40,000$ to $\$ 47,640$ in $1994 .^{22}$ The board was standing firm at three percent per year for three years. ${ }^{23}$ The teachers' health insurance plan was also in dispute. ${ }^{24}$ At 10:30 p.m. on May 27, 1993, the union delivered a strike notice to the home of Superintendent Dr. Norman Namey, ${ }^{25}$ and on June 4, the teachers launched their first strike in the twenty-seven-year history of the district. ${ }^{26}$

The timing of that strike was the subject of one particular cellular telephone conversation between Gloria Bartnicki and Anthony Kane, Jr.,

18 See Leanora Minai, Teachers at WVW Threaten to Strike: The Situation Appears 'Bleak' a School Director Concedes, TIMES LEADER (Wilkes-Barre), May 22, 1993, at A3, available at http://www.times leader.com/archive/ $6865272 . \mathrm{html}$.

19 James Rubin, Union Head: Furlough Slips Add Tension to WVW Contract Talks: Teachers and Board Directors in the Wyoming Valley West School District Returning to Bargaining Table This Week, TIMES LEADER (Wilkes-Barre), Oct. 19, 1992, at A3, available at http://www.timesleader.com/archive/ 6865272.html.

${ }^{20}$ Charles H. Bogino, Volunteer Work Halted by Teachers at WVW: Activities and Chaperoning Are Falling Victim to a Contract Dispute Between Teachers and the School District, TIMES LEADER (Wilkes-Barre), Mar. 19, 1993, at Al, available at http://www.timesleader.com/archive/6865272.html.

${ }^{21}$ Minai, supra note 18.

${ }^{22}$ Id.

${ }^{23}$ Tom Obrzut \& Gina Thackara, Contract Offer Best We Can Do, Says WVW Board Member. Under the Proposal, Teachers Would Receive a 3-Percent Raise Each Year for the Next Three Years, TIMES LEADER (Wilkes-Barre), June 7, 1993, at A3, available at http://www.timesleader.com/archive/ 6865272.html.

${ }^{24}$ Anne Karolyi, WVW Could See Strike in Exam Week: Salary Increases and a Health Insurance Plan Are the Two Chief Points of Contention, the Head of the Teachers' Union Says, TIMES LEADER (Wilkes-Barre), May 29, 1993, at Al, available at http://www.timesleader.com/archive/6865272.html.

${ }^{25}$ Id.

${ }^{26}$ Anne Karolyi, Striking Wyoming Valley West Teachers Picket the High School Friday in Plymouth While Seniors File into the Cafeteria: Economics Lesson Valley West Strike to End Tuesday, but Battle over Contract Will Continue, TIMES LEADER (Wilkes-Barre), June 6, 1993, at A1, available at http://www.timesleader.com/archive/6865272.html. The teachers picketed on Friday and Monday, then went back to school on Tuesday in compliance with a state statute. See id. 
sometime in May. ${ }^{27}$ Bartnicki was employed by the Pennsylvania State Education Association (PSEA) and assigned as a negotiator in the Wyoming Valley West School District contract dispute. ${ }^{28}$ Kane was a teacher at Wyoming Valley West High School and president of the PSEA local, the Wyoming Valley West Education Association. ${ }^{29}$

But it was another remark by Kane that captured the attention of the public-and the legal system-when the conversation was broadcast several months later: "If they're [the School Directors] not going to move for three percent $(3 \%)$, we're gonna have to go to their, their homes . . . to blow off their front porches, we'll have to do some work on some of those guys ....."30 How the public came to know of this conversation forms the factual predicate of this case.

The contentious contract negotiations prompted the formation of a citizens' group called the Wyoming Valley West Taxpayers' Association to oppose the teachers' union proposals.' Sometime after the conversation took place, still during the spring of 1993, the president of that organization, Jack Yocum, allegedly found a five-minute tape of the conversation in his mailbox. ${ }^{32}$ Yocum claimed not to know who made the tape or why, ${ }^{33}$ but he listened to it, identified the voices, played it for some school board members, and gave copies of the tape to Frederick W. Vopper. ${ }^{34}$ Vopper had a news and public affairs talk show under the name "Fred Williams" that was broadcast on WILK Radio and simulcast on WGBI-AM."

By all accounts, Vopper did nothing with the tape until late September. ${ }^{36}$ By then, contract negotiations had completely broken down, the dispute had been submitted to non-binding arbitration, the arbitrator had sided with the teachers' union, and the school board had rejected the

27 A transcript of the conversation between Bartnicki and Kane was prepared by WILK Radio, one of the defendants in Bartmicki v. Vopper, and a copy of the transcript is attached to the Media Defendants' answer (29a-30a) and their motion for summary judgment, as Exhibit "A" (315a-326a). Amended Brief of Appellants at 8, Bartnicki v. Vopper, 200 F.3d 109 (3d Cir. 1999) (No. 98-7156), 1998 WL 34082380 , at *8. The exact date of the conversation is not in the record.

${ }^{28}$ Id. at 3,1998 WL 43082380 , at *3.

29 Id.

30 Id. at 8, 1998 WL 43082380 , at *8.

31 Id. at 6, 1998 WL 43082380 , at *6.

32 Id. at 7, 1998 WL 43082380, at *7 (citing Yocum's deposition).

${ }^{33}$ Id.

34 Id. Yocum also gave copies to Rob Neyhard at WARM Radio, and Kane's deposition states that copies were given to the Times Leader and Citizens' Voice newspapers, as well as television stations WNEP-TV and WBRE-TV. Only Yocum, Vopper, and the two radio stations that carried Vopper's program were named as defendants in the subsequent lawsuit. Id. at 7-8, 1998 WL 43082380, at *7-8.

${ }_{35}$ Id. at $7,1998 \mathrm{WL} 43082380$, at *7.

${ }^{36}$ See id. at 8, 1998 WL 43082380 , at *8. 
arbitrator's decision. ${ }^{37}$ About the same time, Vopper, who had been critical of the teachers' union in the past,$^{38}$ began airing the tape repeatedly, while adding bomb-like sound effects. ${ }^{39}$ Intended or not, the tapes had the effect of further inflaming the contract dispute, ${ }^{40}$ and the Luzerne County District Attorney launched an investigation at the behest of the school board. ${ }^{41}$ In the end, neither his investigation nor another undertaken by the PSEA could determine who actually made the tape. ${ }^{42}$ According to Vopper's first attorney, the question remains unanswered to this day. ${ }^{43}$

The contract dispute was ultimately settled in November after the school board offered salary increases of sixteen percent over four years, ${ }^{44}$ but the controversy over Vopper's broadcasts continued; in August 1994, Bartnicki and Kane filed a complaint in the U.S. District Court for the Middle District of Pennsylvania against Vopper and the parent companies of the stations that carried his show (the "media defendants") under civil suit provisions of federal and state wiretap laws. ${ }^{45}$ The unknown persons who intercepted the conversation were also named as John Doe and Jane Doe. $^{46}$

The media defendants retained Donald $\mathrm{H}$. Brobst of the Wilkes-Barre law firm Rosenn, Jenkins \& Greenwald, L.L.P., to represent them in district

37 Anne Karolyi, Arbitrator Suggests Raises at WVW: The Negotiator Says Teachers Should Receive Their Requested Salary Increase, but Directors Seem Unwilling to Sway from Their Offer, TIMES LEADER (Wilkes-Barre), Sept. 28, 1993, at A3, available at http://www.timesleader.com/archive/ $6865272 . \mathrm{html}$. The Supreme Court opinion says the parties accepted the arbitrator's proposal, but the contemporaneous news reports seem more reliable on this point. See Bartnicki v. Vopper, 512 U.S. 514, 519 (2001).

38 Bartnicki, 512 U.S. at 519.

39 Brief of Appellees at 5, Bartnicki v. Vopper, 200 F.3d 109 (3d Cir. 1999) (No. 98-7156), 1998 WL 34083465, at *5. Indeed, the District Attomey for Wilkes-Barre testified that Vopper and WILK were so irresponsible that his office refused to send press releases to WILK. Brief of Pennsylvania State Education Ass'n as Amicus Curiae in Support of Plaintiffs-Appellees at 3 n.1, Bartnicki, 200 F.3d 109 (No. 98-7156), 1998 WL 34083460, at *3 n.1.

40 Anne Karolyi, Alleged Threat by Union Heightens WVW Friction: Those Who Have Heard the Tape Allege Someone Says School Directors Could Suffer Property Damage at Their Homes if They Do Not Make Contract Concessions, TIMES LEADER (Wilkes-Barre), Oct. 3, 1993, at A3, available at http://www.timesleader.com/archive/6865272.html.

${ }^{41}$ See Jim Van Nostrand, DA Will Probe Alleged Threats upon WVW Request: Several Directors Say They Will Ask Fellow Board Members to Formally Request an Investigation, Perhaps at Tonight's Meeting, TIMEs LEADER (Wilkes-Barre), Oct. 2, 1993, at A3, available at http:/www.timesleader.com/ archive $/ 6865272 . \mathrm{html}$.

42 Amended Brief of Appellants, supra note 27, at 7, 1998 WL 34082380, at *7.

43 Interview with Donald H. Brobst, Rosenn, Jenkins \& Greenwald, L.L.P., in Wilkes-Barre, Pa. (June 25, 2010) (recording on file with author).

44 Anne Karolyi, The Battle Ends: Valley West Board OKs Pact on 5-4 Vote, TIMES LEADER (Wilkes-Barre), Nov. 4, 1993, at A3, available at http://www.timesleader.com/archive/6865272.html.

45 See supra note 13.

46 Amended Brief of Appellants, supra note 27, at 3, 1998 WL 34082380, at *3. 
court. ${ }^{47}$ Brobst had long represented WILK and its then-parent company, Keymarket of NEPA (Northeastern Pennsylvania), Inc., and this was neither the first nor the last case he had involving Fred Vopper. ${ }^{48}$ In addition to his defamation and other media law work, Brobst specialized in employment law cases, ${ }^{49}$ and he both initiated and defended cases brought under $\S 1983$ of title 42 of the U.S. Code, which gives plaintiffs a federal cause of action when deprived of a constitutional right under color of state law.

The media defendants filed their answer in September..$^{50}$ The following February, they consented to the plaintiffs' amending their complaint to add Yocum as a defendant. ${ }^{51}$ Yocum answered on June 30, $1995 .^{52}$ After extensive discovery, the plaintiffs and the defendants moved for summary judgment, with both defendants asserting a First Amendment right to disclose the conversation. ${ }^{53}$ By Memorandum and Order dated June 17, 1996, the District Court denied both motions, ruling that the circumstances of the interception and the defendants' knowledge of them represented genuine issues of material fact, but that imposing liability on the defendants would not violate the First Amendment. ${ }^{54}$

The court denied the defendants' subsequent motion to reconsider in November, and in January 1998, the court certified that its orders were appealable. ${ }^{55}$ On January 14 , the media defendants filed an appeal in the

47 See Interview with Donald H. Brobst, supra note 43.

48 See id.

49 See id.

50 Amended Brief of Appellants, supra note 27, at 3, 1998 WL 34082380, at *3.

${ }^{51}$ Id. at 4, 1998 WL 34082380 , at *4.

$52 I d$.

53 Id.

54 Bartnicki v. Vopper, No. 3:CV-94-1201, 1996 U.S. Dist. LEXIS 22517, at*12 (M.D. Pa. June 14, 1996).

55 Amended Brief of Appellants, supra note 27, at 2, 1998 WL 34082380 , at *2. The court ruled that the orders denying summary judgment "involved controlling questions of law as to which there is substantial ground for difference of opinion and that an immediate appeal . . . will materially advance the ultimate determination of this litigation." $I d$. at 5,1998 WL 34082380 , at $* 5$. As articulated by the Third Circuit, those questions were:

(1) whether the imposition of liability on the media Defendants under the [wiretapping statutes] solely for broadcasting the newsworthy tape on the Defendant Fred Williams' radio news/public affairs program, when the tape was illegally intercepted and recorded by unknown persons who were not agents of the Defendants, violates the First Amendment; and (2) whether imposition of liability under the aforesaid [wiretapping statutes] on Defendant Jack Yocum solely for providing the anonymously intercepted and recorded tape to the media Defendants violates the First Amendment. 
U.S. Court of Appeals for the Third Circuit with the concurrence of the other parties to the litigation. ${ }^{56}$ The Third Circuit granted the petition on February $26,{ }^{57}$ and after receiving briefs from the parties ${ }^{58}$ and the PSEA as amicus curiae, ${ }^{59}$ heard oral arguments on October 5 . The United States, which intervened as of right and at the invitation of the court to defend the constitutionality of the federal statute, ${ }^{60}$ filed a brief on November 17 , $1998{ }^{61}$ but to no avail. On December 27, 1999, the Third Circuit reversed the District Court, ${ }^{62}$ and the U.S. Supreme Court granted certiorari on June $26,2000 .^{63}$

\section{DistRICT COURT: BATTLE OF THE PRECEDENTS}

In his motion for summary judgment, Brobst had argued for the media defendants that Bartnicki and Kane could not prove that their telephone conversation had been illegally - that is, intentionally and not inadvertently-intercepted, or that Vopper knew or had reason to know that the telephone conversation was illegally intercepted. ${ }^{64} \mathrm{He}$ also argued that Bartnicki had no reasonable expectation of privacy in the conversation, which took place on a cellular telephone that she acknowledged was susceptible to interception. ${ }^{65}$ Brobst later conceded that neither of these factual arguments was persuasive, and that he staked everything on the First Amendment argument from the beginning. ${ }^{66}$ Brobst's First Amendment argument relied almost exclusively on Landmark Communications, Inc. v. Virginia and the line of constitutional privacy cases, beginning with Cox Broadcasting Corp. v. Cohn and ending with Florida Star v. B.J.F, ${ }^{67}$ to

56 Amended Brief of Appellants, supra note 27, at 2, 1998 WL 34082380, at *2.

57 Id.

58 See Brief of Appellees, supra note 39, 1998 WL 34083465; Addendum to Brief of Appellees, Bartnick, 200 F.3d 109 (No. 98-7156), 1998 WL 34082372; Brief on Behalf of Appellee, Jack Yocum, Bartnicki, 200 F.3d 109 (No. 98-7156), 1998 WL 34082376; Amended Brief of Appellants, supra note 27, 1998 WL 34082380.

59 See Brief of Pennsylvania State Education Ass'n as Amicus Curiae in Support of PlaintiffsAppellees, supra note 39, 1998 WL 34083460.

60 Brief for the United States at 1, Bartnicki, 200 F.3d 109 (No. 98-7156), 1998 WL 34082480, at *1.

61 Id.

62 Bartnicki, 200 F.3d at 129.

63 Bartnicki v. Vopper, 530 U.S. 1260 (2001).

64 Brief in Support of Media Defendants' Motion for Summary Judgment, Bartnicki v. Vopper, No. 3:CV-94-1201, at 19 (M.D. Pa. July 1996) (on file with author)

65 Id. at 21 .

66 Interview with Donald H. Brobst, supra note 43.

67 Brief in Support of Media Defendants' Motion for Summary Judgment, supra note 64, at 14-19. See infra Part II.A for a discussion of this line of cases. Throughout this Article, the lawyers and judges 
which Landmark belongs. Those cases held that "where the media lawfully obtains truthful information about a matter of public significance or concern, government officials may not constitutionally punish the publication of that information absent the need to further a government interest of a higher order. ${ }^{, 68}$ Brobst later said he focused on Landmark in particular because the governmental interests there-maintaining the reputation of the judges and the institutional integrity of the courts-were far greater than the privacy interests protected in this case. ${ }^{69}$

To U.S. District Court Judge Edwin M. Kosik, however, the Bartnicki case essentially countered Brobst's Landmark rule with another wellestablished First Amendment principle: that "generally applicable laws 'do not offend the First Amendment simply because their enforcement against the press has incidental effects on its ability to gather and report the news." "Judge Kosik referred to this principle as the Cohen doctrine after Cohen v. Cowles Media, the only case cited for that proposition in his opinion, ${ }^{71}$ despite its much earlier origins. ${ }^{72} \mathrm{~A}$ closer examination of the two conflicting precedents follows.

\section{A. The Constitutional Privacy Cases}

The genesis of the notion that plaintiffs ought to be able to recover for an invasion of their privacy was an 1890 Harvard Law Review article by Louis Brandeis and his law partner Samuel Warren. ${ }^{73}$ The concept did not exist in English common law, and invasion of privacy is often called the only truly American tort. Dean William L. Prosser's classification scheme for the American common law privacy torts included misappropriation of name or likeness, publicity in a false light, intrusion on seclusion, and disclosure of private facts. ${ }^{74}$ Apart from the five cases that substantively parallel the tort of disclosure of private facts - which are the central focus

will variously reference this line, and the principle derived from it, as the Landmark, Daily Mail, or Florida Star rule or principle.

${ }_{68}$ Bartnicki v. Vopper, No. 3:CV-94-1201, 1996 U.S. Dist. LEXIS 22517, at *10 (M.D. Pa. June 14, 1996).

69 Interview with Donald H. Brobst, supra note 43.

70 Bartnicki, 1996 U.S. Dist. LEXIS 22517, at*11 (quoting Cohen v. Cowles Media Co., 501 U.S. $663,669(1991))$.

${ }^{71}$ Id. See infra Part II.B for a discussion of this case.

72 As applied to First Amendment claims, the doctrine goes back at least as far as Grosjean $v$. American Press Co., which contained Justice Sutherland's dictum that owners of newspapers are not "immune from any of the ordinary forms of taxation for support of the government." 297 U.S. 233, 250 (1936).

73 Samuel D. Warren \& Louis D. Brandeis, The Right to Privacy, 4 HARV. L. REV. 193 (1890).

74 William L. Prosser, Privacy, 48 CALIF. L. REV. 383, 389 (1960). 
of this section-only three privacy cases involving the press ever reached the U.S. Supreme Court.

In the 1967 case of Time, Inc. v. Hill, the Court declined to award damages in a false light privacy claim under a New York statute absent a showing of actual malice. ${ }^{75}$ In the 1974 case of Cantrell v. Forest City Publishing Co., the Court upheld a jury verdict finding that a Cleveland Plain Dealer reporter had knowingly placed the Cantrell family in a false light through numerous inaccuracies and false statements in his article about them. ${ }^{76}$ And in the 1977 case of Zacchini v. Scripps-Howard Broadcasting Co., the Court held that an Ohio television station misappropriated the entire act of a circus "human cannonball" by filming and broadcasting his entire, fifteen-second act. ${ }^{77}$

Of far greater importance, however, was the series of five privacyrelated cases that reached the Court between 1975 and 1989. None of these cases directly implicated the tort of public disclosure of private facts; the press rarely lost those cases in the state courts because of an absolute "newsworthiness" defense that was said to have "swallowed" the tort itself. The cases that did get to the Court, however, were all based, directly or indirectly, on statutes that criminalized the publication of truthful, but embarrassing, information. Sometimes they were characterized as prior restraints, sometimes as subsequent punishment.

On August 18, 1971, Cynthia Leslie Cohn, seventeen, was raped and suffocated to death by six high school boys following a drinking party in Sandy Springs, Fulton County, Georgia. ${ }^{78}$ In April 1972, when the six perpetrators were arraigned, five pled guilty to rape-the murder charges against them having been dropped-and a date was set for the trial of the youth who pled not guilty. ${ }^{79}$ A reporter covering the case for WSB-TV duly broadcast the story later that day, including, for the first time in any media, the name of the victim. ${ }^{80}$ The reporter had learned the name from personal observation of the proceedings and from the indictments, which were public records available to anyone who asked. ${ }^{81}$ The next month, Martin Cohn, Cynthia Cohn's father, filed a lawsuit against the Cox Broadcasting Corp., the owner of WSB-TV, for invasion of privacy and for violating a Georgia

75385 U.S. 374,397 (1967).

76419 U.S. 245, 252-53 (1974).

77433 U.S. 562, 563-66 (1977).

78 Cox Broad. Corp. v. Cohn, 420 U.S. 469, 471, 474 n.5 (1975).

79 Id. at 472.

80 Id. at $473-74$.

81 Id. at $472-73$. 
statute that prohibited the publication or broadcasting of the name of any rape victim. ${ }^{82}$

The trial court held that the statute gave Cohn a private right of action against Cox, notwithstanding the broadcaster's constitutional claims, and granted Cohn summary judgment as to liability, with damages to be considered at a later jury trial. ${ }^{83}$ On appeal, the Georgia Supreme Court held that the statute did not give Cohn a private right of action, so summary judgment was inappropriate, but also that Cohn's common law invasion of privacy claim was not precluded by the First Amendment. ${ }^{84}$ On a motion for rehearing, the state supreme court held that the statute was an authoritative declaration of state policy to the effect that the name of a rape victim was not a matter of public concern, so the right to disclose that information was not protected by the First Amendment. ${ }^{85}$ The U.S. Supreme Court reversed in Cox Broadcasting Corp. v. Cohn. ${ }^{86}$

Writing for a nearly unanimous Court-only Justice Rehnquist dissented-Justice White got to the heart of the matter. "Because the gravamen of the claimed injury is the publication of information, whether true or not, the dissemination of which is embarrassing or otherwise painful to an individual, it is here that claims of privacy most directly confront the constitutional freedoms of speech and press." constitutional balance cautiously, Justice White largely restricted his holding to the facts at hand. The state may not, he wrote, "impose sanctions on the accurate publication of the name of a rape victim obtained from public records-more specifically, from judicial records which are maintained in connection with a public prosecution and which themselves are open to public inspection. ${ }^{, 88}$ If the state wanted to keep such information from the press, the Court said, it would have to find some way to avoid public documentation or other exposure of private information, possibly by sealing court records containing such facts. ${ }^{89}$ Only Justice Douglas would have ruled on broader grounds: that "there is no power on the part of government to suppress or penalize the publication of "news of

82 Id. at 474.

${ }^{83} \mathrm{Id}$.

84 Id. at 474-75.

85 Id. at 475.

86 Id at 476.

87 Id. at 489.

88 Id. at 491.

${ }^{89}$ Id. at 495-96. 
the day. $"{ }^{90}$ Justice Rehnquist's dissent turned on jurisdiction, not the merits. ${ }^{91}$

While only regional media companies participated in the Cox case, the next privacy case to reach the Court drew the attention of the American Newspaper Publishers Association (ANPA). Oklahoma Publishing Co. v. District Court in and for Oklahoma County was not a tort case at all, ${ }^{92}$ but rather challenged an injunction issued by the county court prohibiting the news media from "publishing, broadcasting, or disseminating, in any manner, the name or picture" of an eleven-year-old boy alleged to have shot and killed a railroad switchman. ${ }^{93}$ Reporters were able to learn his name and take his photograph during and after an open detention hearing, and they used both in the newspaper, radio, and television stories that followed. ${ }^{94} \mathrm{~A}$ few days later, when the boy appeared in court again for arraignment, the judge closed the proceeding and issued the injunction. ${ }^{95}$ On appeal, the Oklahoma Supreme Court affirmed the judge's order, but the U.S. Supreme Court stayed the order. ${ }^{96}$ It granted certiorari and, in the same per curiam opinion, reversed. ${ }^{97}$

As if to illustrate the relationship between prior restraint and privacy cases, the Court, relying on both Cox and Nebraska Press v. Stuart, ${ }^{98}$ held that "the First and Fourteenth Amendments will not permit a state court to prohibit the publication of widely disseminated information obtained at court proceedings which were in fact open to the public." ${ }^{\prime 99}$ The Court's very brief opinion closely tracked the arguments made by ANPA in its amicus brief, but did not follow ANPA's suggestion for a general rule to avoid "a constant stream of minor fact variations which will needlessly take up the time of this Court and of the press in preventing encroachments upon the First and Fourteenth Amendments by trial judges who do not yet believe or perhaps understand the teachings of this Court . . ."100 The Court

90 Id. at 501 (Douglas, J., concurring).

91 Id. at 501 (Rehnquist, J., dissenting).

92430 U.S. 308 (1977) (per curiam).

93 Id. at 308-09 (internal quotation marks omitted).

94 Id. at 309.

95 Id. at 308,309 n.1.

96 Id. at 308.

97 Id. at 309.

98427 U.S. 539 (1976) (reversing a court order prohibiting publication of facts adduced in open trial).

99 Okla. Publ'g Co., 430 U.S. at 310.

100 Brief of Amicus Curiae American Newspaper Publishers Ass'n at 18, Okla. Publ'g Co., 430 U.S. 308 (No. 76-867), 1977 WL 189322, at*18. 
continued to resist formulating a broad, general rule in the next privacyrelated case the following year.

On October 4, 1975, Landmark's Virginian-Pilot published an article that accurately reported on a pending inquiry by the Virginia Judicial Inquiry and Review Commission and identified the state judge whose conduct was being investigated. ${ }^{101} \mathrm{~A}$ month later, a grand jury indicted Landmark for violating a state statute by "unlawfully divulg[ing] the identification of a Judge of a Court not of record, which said Judge was the subject of an investigation and hearing" by the Commission. ${ }^{102}$ Landmark was convicted of a misdemeanor in a bench trial and fined $\$ 500 .^{103}$ The Virginia Supreme Court affirmed the conviction, citing the need to protect the judge's reputation from the publicity that might attend frivolous claims; preserve public confidence in the judicial system; and protect complainants and witnesses before the Commission. ${ }^{104}$ Landmark appealed to the U.S. Supreme Court, which granted certiorari. ${ }^{105}$

In contrast to Cox and even Oklahoma Publishing, Landmark attracted the attention of a substantial number of media companies and press associations. ${ }^{106}$ The media companies argued that under the Constitution, none of the purported interests cited by the Virginia Supreme Court could be protected by imposing criminal sanctions on the press and calling for a rule barring accurate reports of government affairs. ${ }^{107}$ The press associations similarly argued that the Constitution barred states from imposing criminal sanctions for publishing information on the public duties of public officials. ${ }^{108}$ As before, the Court shied away from any generalized pronouncement. Writing for a nearly unanimous Court, Chief Justice

101 Landmark Commc'ns, Inc. v. Virginia, 435 U.S. 829, 831 (1978).

$102 I d$.

103 Id. at 832.

104 Id. at 833

105 Id. at 834 (indicating that the Court noted probable jurisdiction and reversed the Virginia Supreme Court's decision).

106 See Brief Amicus Curiae of American Newspaper Publishers Ass'n, Landmark Commc'ns, Inc., 435 U.S. 829 (No. 76-1450), 1977 WL 189715 [hereinafter Brief of Media Companies]; Brief of the National Newspaper Ass'n \& the Arizona Newspapers Ass'n et al. as Amici Curiae in Support of Appellant, Landmark Commc'ns, Inc., 435 U.S. 829 (No. 76-1450), 1977 WL 189717 [hereinafter Brief of Press Associations]; Brief of the Washington Post Co. \& CBS Inc. et al., Amici Curiae, in Support of Reversal, Landmark Commc'ns, Inc., 435 U.S. 829 (No. 76-1450), 1977 WL 189719; Motion of the ACLU and the ACLU of Virginia for Leave to File Brief Amici Curiae, and Brief Amici Curiae, Landmark Commc'ns, Inc., 435 U.S. 829 (No. 76-1450), 1977 WL 189721.

107 Brief of Media Companies, supra note 106, 1977 WL 189719, at*16-33.

108 Brief of Press Associations, supra note 106, 1977 WL 189717, at *4-15. 
Burger found it "unnecessary to adopt this categorical approach to resolve the issue. $" 109$ He continued:

The narrow and limited question presented, then, is whether the First Amendment permits the criminal punishment of third persons who are strangers to the inquiry, including the news media, for divulging or publishing truthful information regarding confidential proceedings of the Judicial Inquiry and Review Commission. We are not here concerned with the possible applicability of the statute to one who secures the information by illegal means and thereafter divulges it.

$\ldots$

...We conclude that the publication Virginia seeks to punish under its statute lies near the core of the First Amendment, and the Commonwealth's interests advanced by the imposition of criminal sanctions are insufficient to justify the actual and potential encroachments on freedom of speech and of the press which follow therefrom. ${ }^{110}$

Even without propounding the general rule sought by the press, the Court had, in these three cases, begun to make clear that privacy interestsincluding the name of a rape victim, a juvenile offender, or even a judge merely accused of wrongdoing-would not be enough to overcome the presumptive right of the press to publish truthful information, lawfully acquired, on matters of public concern, even if the publication was otherwise prohibited by a state's legislature or its courts. ${ }^{111}$ In Smith v. Daily Mail Publishing Co., the Court would make that rule explicit. ${ }^{112}$

The 1979 case, like Oklahoma Publishing, involved an indictment against two West Virginia newspapers for violating state law by publishing, without a court's permission, the name of a fourteen-year-old who had shot and killed a high school classmate. ${ }^{113}$ In this case, however, the reporters did not obtain the name in open court, but by monitoring the police band radio frequency, going to the scene, and interviewing witnesses, police, and a prosecutor. ${ }^{114}$ The papers sought and won a writ of prohibition against prosecution from the West Virginia Supreme Court, which held that prosecution would be unconstitutional under recent U.S. Supreme Court decisions, but the attorney general of West Virginia filed a successful

\footnotetext{
109 Landmark Commc'ns, Inc., 435 U.S. at 838.

$110 I$ Id. at 837,838 (citations omitted).

III Id. at $841-42$.

112443 U.S. 97, 105-06 (1979)

113 Id. at $99-100$.

114 Id. at 99.
} 
petition for certiorari on behalf of the trial judge, Robert K. Smith. ${ }^{115}$ Once again, the press amici came out in force to support the newspapers. ${ }^{116}$ Once again, the ACLU added its voice to that of the press. ${ }^{117}$ Once again, Floyd Abrams, who had represented Landmark Communications, was representing the newspaper. ${ }^{118}$ Once again, the Chief Justice wrote the opinion for a nearly unanimous Court. ${ }^{119}$

Because of the language of the statute requiring a court order before publishing the name of a juvenile offender, the press amici tended to characterize the statute as a prior restraint-even though the information had already been published and the case reached the Court through a criminal prosecution. ${ }^{120}$ Chief Justice Burger agreed after a fashion:

Whether we view the statute as a prior restraint or as a penal sanction for publishing lawfully obtained, truthful information is not dispositive because even the latter action requires the highest form of state interest to sustain its validity. Prior restraints have been accorded the most exacting scrutiny in previous cases. However, even when a state attempts to punish publication after the event it must nevertheless demonstrate that its punitive action was necessary to further the state interests asserted. Since we conclude that this statute cannot satisfy the constitutional standards defined in Landmark Communications, Inc., we need not decide whether, as argued by respondents, it operated as a prior restraint. ${ }^{121}$

But Chief Justice Burger went further and gave the press the general rule it had been seeking. He pointed out that in the previous cases-Cox, Oklahoma Publishing, and Landmark Communications - the press received the information from the government or government sources, so those cases did not directly control the outcome here, where the press gathered the information through routine reporting techniques. ${ }^{122}$ Asserting that it made no difference- "[a] free press cannot be made to rely solely upon the

115 Id. at 100.

116 Motion of Chicago Tribune Co. for Leave to File Brief Amicus Curiae and Brief Amicus Curiae, Daily Mail Publ'g Co., 443 U.S. 97 (No. 78-482), 1979 WL 199841; Motion of American Newspaper Publishers Ass'n for Leave to File Brief Amicus Curiae and Brief Amicus Curiae, Daily Mail Publ'g Co., 443 U.S. 97 (No. 78-482), 1979 WL 199845 [hereinafter Brief of American Newspaper Publishers Ass'n]; Motion of American Society of Newspaper Editors \& Radio Television News Directors Ass'n et al. for Leave to File Brief, Amici Curiae, Daily Mail Publ'g Co., 443 U.S. 97 (No. 78-482), 1979 WL 199839.

117 Motion of the ACLU for Leave to File, and Brief Amicus Curiae, Daily Mail Publ'g Co., 443 U.S. 97 (No. 78-482), 1979 WL 213634.

118 Daily Mail Publ'g Co., 443 U.S. at 98.

119 Id.

120 Brief of American Newspaper Publishers Ass'n, supra note 116, 1979 WL 199845, at *10.

121 Daily Mail Publ'g Co., 443 U.S. at 101-02 (citations omitted).

122 Id. at 103. 
sufferance of government to supply it with information" 123 - Chief Justice Burger said those cases "suggested" the general rule: "if a newspaper lawfully obtains truthful information about a matter of public significance then state officials may not constitutionally punish publication of the information, absent a need to further a state interest of the highest order." 24

Articulation of a rule seemed to put an end to this kind of litigation, as Justice White had once predicted, ${ }^{125}$ but ten years later, another similar case again reached the Court. In Florida Star v. B.J.F., a novice reporter picked up a police report that identified sexual assault victim B.J.F. by her full name from the Jacksonville police press room. ${ }^{126}$ The unedited report had been left there inadvertently. ${ }^{127}$ When the paper ran a brief item using her full name, contrary to its own editorial policy and a Florida statute, B.J.F. sued on a theory of negligence per se. ${ }^{128}$ The trial judge agreed that the newspaper's violation of the statute gave rise to a negligence per se claim, and a jury awarded B.J.F. $\$ 75,000$ in compensatory and $\$ 25,000$ in punitive damages. ${ }^{129}$ That was affirmed per curiam by an intermediate court; the Florida Supreme Court declined to review. ${ }^{130}$ The newspaper petitioned successfully for certiorari. ${ }^{131}$

Perhaps the change in court personnel over the decade-Justices Burger, Stewart, and Powell were gone; Justices Scalia, O'Connor, and Kennedy had arrived-made this a much tougher decision. Or perhaps it was the change in leadership from Chief Justice Burger to Chief Justice Rehnquist. On its facts, this case did not look all that different from the previous cases. But Justice White, who dissented along with Chief Justice Rehnquist and Justice O'Connor, declared that the six-to-three Florida Star decision was the "bottom of the slippery slope" created by the previous decisions ${ }^{132}$-in each of which he had concurred.

Writing for the majority, Justice Marshall said Cox did not control the case because a police report is not a court document and does not carry with it the constitutionally significant notion of open trials. ${ }^{133}$ Daily Mail provided the proper rule, Justice Marshall said, but he tweaked Chief

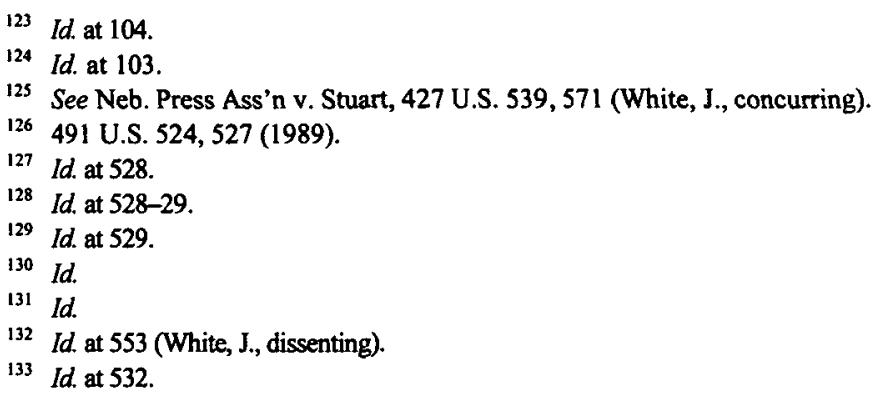


Justice Burger's formulation to add a "narrowly tailored" requirement: "[W]here a newspaper publishes truthful information which it has lawfully obtained, punishment may lawfully be imposed, if at all, only when narrowly tailored to a state interest of the highest order . . .,"134 And that was not the case here. ${ }^{135}$ In an opinion that reasonably tracked the substance of the press amici briefs, which were substantial, ${ }^{136}$ Justice Marshall pointed out that a rape victim's privacy might be a state interest of the highest order under some circumstances, but not where the government itself provided the information, albeit inadvertently; where the statute covered only the mass media, and not other forms of dissemination, including neighborhood gossip; and where no fault was required for liability, making the publication of truthful information even less protected than publication of a libelous falsehood. $^{137}$

\section{$B$. Cohen v. Cowles Media ${ }^{138}$}

Dan Cohen was a Minneapolis public relations executive associated with the 1982 gubernatorial campaign of Independent-Republican Wheelock Whitney. ${ }^{139}$ In late October 1982, just six days before the general election, Cohen contacted a number of journalists in the St. PaulMinneapolis area, offering to give them information concerning a Democratic-Farmer-Laborite (DFL) candidate in exchange for a promise of confidentiality. ${ }^{140}$ Among the journalists accepting the offer were reporters for the St. Paul Pioneer Press and the Minneapolis Star Tribune. ${ }^{141}$

Cohen provided the reporters with public court records showing that Marlene Johnson, the DFL candidate for Lieutenant Governor, had

134 Id. at 541 .

135 Id.

136 Brief of Amici Curiae American Newspaper Publishers Ass'n \& the N.Y. Times Co. et al., Fla. Star, 491 U.S. 524 (No. 87-329), 1988 WL 1026321; Brief Amici Curiae of the Reporters Committee for Freedom of the Press \& Associated Press et al. in Support of the Appellant, Fla. Star, 491 U.S. 524 (No. 87-329), 1988 WL 1026323.

137 Fla. Star, 491 U.S. at 538-41.

138501 U.S. 663 (1991).

139 Id. at 665. See also Bill Salisbury, Burning the Source, WASH. JOURNALISM REV., Sept. 1991, at 18. Much of this history and analysis is adapted from Eric B. Easton, Two Wrongs Mock a Right: Overcoming the Cohen Maledicta that Bar First Amendment Protection for Newsgathering, 58 OHIO ST. L.J. 1135 (1997) [hereinafter Two Wrongs].

140 Salisbury, supra note 139, at 19-20. According to Salisbury, the Pioneer Press reporter involved, Cohen refused even to describe the information until he received a promise of confidentiality. Id. at 20.

141 Id. Associated Press reporter Gary Nelson and WCCO-TV reporter Dave Nimmer also received the information. Nelson's stories did not name Cohen, while Nimmer decided the story was not newsworthy. Id. 
previously been arrested for unlawful assembly and petit theft. ${ }^{142}$ The unlawful assembly charges, which grew out of a civil rights demonstration, were ultimately dismissed. ${ }^{143}$ The candidate had been convicted on the theft charge, which involved a minor shoplifting offense while she had been emotionally distraught, but the conviction was later vacated. ${ }^{144}$

Editors at both the Pioneer Press and the Star Tribune independently decided to print the story and, over their reporters' protests, to include the name of the source. ${ }^{145}$ While the Pioneer Press editors buried Dan Cohen's name deep in the story, the Star Tribune editors featured it, apparently reasoning that the value of the story, if any, lay in Cohen's conduct, not Johnson's. ${ }^{146}$ The Star Tribune also attacked Cohen in its editorial pages, but neither paper reported that it had broken a promise of confidentiality with Cohen.

Cohen lost his job when the story broke, ${ }^{148}$ and later sued the newspapers' publishers alleging fraudulent misrepresentation and breach of contract. ${ }^{149}$ Overcoming the publishers' First Amendment claims, Cohen won $\$ 200,000$ in compensatory damages and $\$ 500,000$ in punitive damages at trial. ${ }^{150}$ The Minnesota Court of Appeals struck down the punitive damage award after finding that Cohen had failed to establish a fraud claim. ${ }^{151}$ The Minnesota Supreme Court struck down the compensatory damage award, holding a contract action "inappropriate" under the circumstances. ${ }^{152}$

During oral argument before the Minnesota Supreme Court, one of the justices had asked a question about estoppel, a cause of action in equity that might serve as an alternative to Cohen's contract claim in enforcing the reporters' promises. ${ }^{153}$ Addressing that issue in its opinion, the court found it necessary to "balance the constitutional rights of a free press against the

${ }^{142}$ Cohen, 501 U.S. at 665.

${ }^{143} I d$.

144 Id. at $665-66$.

145 Id. at 666

146 Salisbury, supra note 139, at 21-22.

${ }^{147}$ Id.

148 Cohen said he was fired, and that position was adopted by the Supreme Court. Cohen, 501 U.S. at 666. According to Salisbury, his supervisor said he resigned. Salisbury, supra note 139, at 22.

${ }_{149}$ Cohen, 501 U.S. at 666.

150 Id.

151 Cohen v. Cowles Media Co., 445 N.W.2d 248, 260 (Minn. Ct. App. 1989).

152 Cohen v. Cowles Media Co., 457 N.W.2d 199, 203 (Minn. 1990).

153 Cohen, 501 U.S. at 666-67. In a successful promissory estoppel action, one who makes, then breaks, a promise is prevented from denying the existence of contract, despite the absence of a contract formality. See RESTATEMENT (SECOND) OF CONTRACTS $\S 90$ (1981). 
common law interest in protecting a promise of anonymity." 154 In this case, the court said, enforcing the promise would violate the newspapers' First Amendment rights. ${ }^{155}$ The U.S. Supreme Court granted certiorari "to consider the First Amendment implications of this case."

Writing for a five-to-four majority, ${ }^{157}$ Justice White rejected the newspapers' argument that this case was controlled by the line of cases holding that "if a newspaper lawfully obtains truthful information about a matter of public significance then state officials may not constitutionally punish publication of the information, absent a need to further a state interest of the highest order." controlled "by the equally well-established line of decisions holding that generally applicable laws do not offend the First Amendment simply because their enforcement against the press has incidental effects on its ability to gather and report the news." 159

Justice White proceeded to list a number of cases-starting with Branzburg v. Hayes ${ }^{160}$-purporting to demonstrate that enforcement of general laws against the press is not subject to any stricter scrutiny than would be applied to enforcement against other persons or organizations. ${ }^{161}$ Finding Minnesota's doctrine of promissory estoppel just such a "law of general applicability," Justice White had no problem applying it to the press. ${ }^{162}$ He even suggested that the newspapers' breaking their promises might serve as a predicate for finding their conduct unlawful, thus arguably negating First Amendment protection for the information itself. ${ }^{163}$

Justice White further distinguished Cohen's situation from that of a plaintiff seeking to avoid the strict requirements for establishing a libel claim by stating an alternative cause of action. Specifically citing Hustler Magazine, Inc. v. Falwell, in which the Court denied a claim for intentional infliction of emotional distress without a showing of actual malice, ${ }^{164}$ Justice White pointed out that Cohen had not sought damages for injury to

154 Cohen, 457 N.W.2d at 205.

is5 Id.

156 Cohen, 501 U.S. at 667.

157 Dissenting opinions were written by Justice Blackmun, joined by Justices Marshall and Souter, id. at 672 (Blackmun, J., dissenting), and Justice Souter, joined by Justices Marshall, Blackmun, and O'Connor, $i d$. at 676 (Souter, J., dissenting).

158 Id. at 668-69 (quoting Smith v. Daily Mail Publ'g Co., 443 U.S. 97, 103 (1979)).

159 Id. at 669.

160408 U.S. 665 (1972).

161 Cohen, 501 U.S. at 669-70.

162 Id. at 670.

163 Id. at 671.

164485 U.S. 46, 56 (1988). 
his reputation or state of mind, but rather for the loss of his job and his lowered earning capacity. ${ }^{165}$

Finally, Justice White tackled the argument that allowing the promissory estoppel claim would inhibit the press from disclosing the identity of a confidential source when, as in Cohen, that information is newsworthy. ${ }^{166}$ If true, he said, the "chilling effect" would be "no more than the incidental, and constitutionally insignificant, consequence of applying to the press a generally applicable law that requires those who make certain kinds of promises to keep them."167

Writing for Justices Marshall and Souter in dissent, Justice Blackmun argued that Hustler should have controlled the outcome in this case and that First Amendment protection applies to published speech regardless of the cause of action asserted. ${ }^{168}$ Justice Blackmun saw no meaningful distinction between the kinds of damages sought by Jerry Falwell and those sought by Daniel Cohen. ${ }^{169}$ Justice Souter also filed a separate dissenting opinion, joined by Justices Marshall, Blackmun, and O'Connor, that rejected Justice White's reliance on the doctrine of "generally applicable laws," denying any "talismanic" quality in such laws. ${ }^{170}$ Justice Souter would have found the state's interest in protecting the promise of confidentiality insufficient to outweigh the value of the information revealed in this case. ${ }^{171}$ Nevertheless, the case was remanded to the Minnesota Supreme Court, which reversed its previous position and held the newspapers liable for Cohen's damages on a theory of promissory estoppel. ${ }^{172}$

In his account of this case, Cohen's lawyer, Elliot Rothenberg, called the decision "the worst defeat the media had ever suffered in the Supreme Court." ${ }^{173}$ Even allowing for some self-indulgent boasting, Rothenberg was not far off the mark. ${ }^{174}$ How had the press blown such a big one? Clearly, there was no lack of legal talent applied to the case. Both newspapers brought in new legal teams for the Supreme Court contest-"heavy

167 Id. at 671-72.

168 Id. at 674 (Blackmun, J., dissenting).

$169 \mathrm{Id}$. at 675-76.

${ }^{170}$ Id. at 677 (Souter, J., dissenting).

i7) Id. at 679 .

172 Cohen v. Cowles Media Co, 479 N.W.2d 387, 388 (Minn. 1992).

173 Elliot C. Rothenberg, The Taming of the Press: CoHEN V. CoWles Meda COMPANY 218 (1999).

174 In the interest of full disclosure, Rothenberg cites my own ("[a] pro-media law professor") appraisal of this case as "cut[ting] short the natural evolution of First Amendment protection for newsgathering and set[ting] the stage for many wrongheaded opinions coming out of the lower courts today." Id. at 254 (quoting Easton, Two Wrongs, supra note 139, at 1153). 
artillery," Rothenberg called them. ${ }^{175}$ Supreme Court specialist Stephen M. Shapiro became lead counsel for the Pioneer Press, and eight lawyers signed its brief. ${ }^{176}$ Minneapolis lawyer John French-Harvard Law School and clerk for Justice Felix Frankfurter-took over the Star Tribune campaign, and four lawyers signed its brief. ${ }^{177}$ Rothenberg's description of the press amici is particularly apt:

Shapiro's and French were not the only blue-ribbon lawyers joining the case on the other side. In fact, a battalion of the nation's leading lawyers and most prominent media organizations entered the Supreme Court appeal supporting the Star Tribune and Pioneer Press. Nineteen attorneys from leading law firms in New York, Washington, and Los Angeles filed a third brief opposing mine. Their amicus curiae brief represented the big leagues of American media .... ${ }^{178}$

Nor were the press's arguments off track. Indeed, they paralleled, if not influenced, the arguments of the four dissenting Justices. ${ }^{179}$ Apart from Rothenberg himself, there was no outstanding opposition to the press's position; heavy hitters like the United States and the ACLU did not have a dog in the hunt, and even those in or involved with the media who thoroughly disapproved of the newspapers' conduct stayed out of the Supreme Court action.

Nevertheless, it is not difficult to identify reasons why the press lost this case. Arguably, the case should have ended with the first state supreme court opinion; the state court rejected Cohen's contract claim and Cohen had not raised promissory estoppel. ${ }^{180}$ The First Amendment question, essential to getting the case to the U.S. Supreme Court, need never have been reached. ${ }^{181}$ Timing, too, was a problem for the press. Justice Brennan retired just before the case was heard, and although his successor, Justice Souter, also supported the press's position, Justice Brennan's voice would have been a far more powerful counterweight to Justice White's hostility. ${ }^{182}$

175 Id. at 180.

176 Id.

177 Id.

178 Id; see also Brief of Amici Curiae Advance Publications, Inc. \& American Newspaper Publishers Ass'n et al. in Support of Respondents, Cohen v. Cowles Media, 501 U.S. 663 (No. 90-634) (1991), 1991 WL 11007832.

${ }^{179}$ See Brief of Amici Curiae Advance Publications, Inc. \& American Newspaper Publishers Ass'n et al. in Support of Respondents, supra note 178 , at *3-6.

180 ROTHENBERG, supra note 173 , at $154-55$.

181 Id. at 156.

182 Id. at 158. 
But perhaps the most serious problem of all was the nature of the case itself and the dissention it engendered within the media establishment.

It was, after all, in the nature of Cohen that the press was forced to argue that promises of confidentiality to sources were not serious enough to be considered contracts without weakening the central argument in Branzburg that such promises deserved constitutional protection. ${ }^{183}$ If not altogether untenable, the press's position was at best precarious. It was also highly contentious. Rothenberg quotes University of Minnesota journalism professor Ted Glasser as characterizing the trial as more "between reporters and editors" than between plaintiffs and defendants, ${ }^{184}$ and urging reporters to oppose the newspapers in any appeal. Glasser wrote:

To claim to have a First Amendment right to renege on a reporter's promise not only places the press above the law but denies reporters the very freedom they need to operate in the day-to-day world of journalism. Reporters have every reason to file a friend-of-the-court brief on behalf of Cohen. ${ }^{185}$

There was no reporters' brief at any level, and the Reporters Committee for Freedom of the Press was not a signatory to the press's amicus brief. The Washington Post also declined to join, as did a number of other media companies who might otherwise have been expected to participate. ${ }^{186}$ Rothenberg's petition for certiorari had capitalized on that dissention by quoting star media lawyer Floyd Abrams calling the newspapers' conduct in breaking their reporters' promises of confidentiality 'reprehensible and damaging to all journalists." ${ }^{187}$ Shortly before the decision came down, Abrams again spoke out publicly in a speech and op-ed column, charging that:

[The newspapers] acted in a fashion contrary to core principles of journalistic ethics. They also invited the lawsuit now awaiting decision by the Supreme Court, one that offers enemies of the press a particularly inviting target. What the Minnesota newspapers did was wrong; they should have said so. Why is any defender of the press unwilling to say as much? ${ }^{188}$

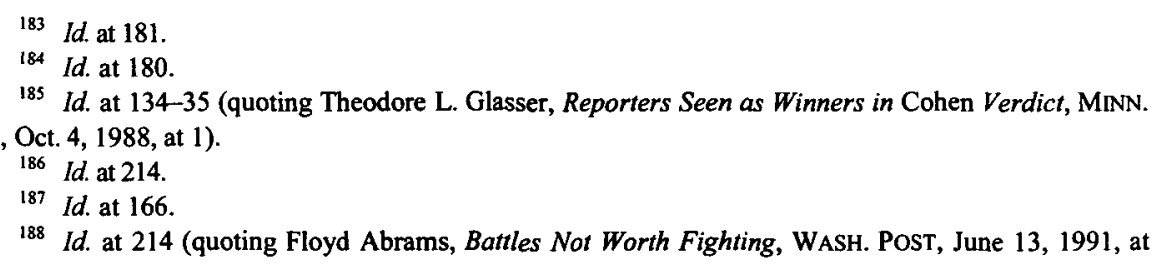


There is no direct evidence that the division within the press over the Cohen case had a significant or even marginal influence on the outcome. Nor was there any direct evidence that differences among media organizations played a significant role in the Court's rejection of constitutional protection for confidential sources in Branzburg v. Hayes, although those differences certainly weakened the campaign for federal shield legislation. There is no doubt, however, that the two most important newsgathering cases ever to reach the U.S. Supreme Court did not show the press in the best light as a constitutional litigator.

\section{The District Court Opinion}

For the district court, the conflict between Landmark and Cohen was easily resolved. According to the court, Landmark only applies where "a state actor attempted to place a prior restraint on specified speech or where the intentional interception was legal but the disclosure was illegal."189 Here, the court said without further explanation, "there exist no statutory provisions specifically designed to chill free speech."190 Thus finding Landmark inapplicable, the court went on to find Cohen controlling. "In reviewing both the federal and the state electronic surveillance laws, we conclude that both acts are matters of general applicability." 191

In his motion for reconsideration, Brobst argued that the court's reliance on Cohen was misplaced and that Landmark did not involve a prior restraint. ${ }^{192}$ The Virginia statute at issue in Landmark was "generally applicable" and did not "single out the press," yet the Supreme Court reversed the newspaper owner's conviction on First Amendment grounds. ${ }^{193}$ This case, Brobst argued, is indistinguishable. ${ }^{194}$ Moreover, he said, by breaking its promise to Cohen, the press arguably obtained its information unlawfully; here, there was no question that the press obtained its information lawfully from Yocum, whatever might have happened earlier. ${ }^{195}$ Perhaps recognizing that engaging in a serious analysis of the issue before it on a motion for summary judgment was probably a waste of

A21).

${ }_{189}$ Bartnicki v. Vopper, No. 3:CV-94-1201, 1996 U.S. Dist. LEXIS 22517, at *10 (M.D. Pa. June $14,1996)$

190 Id.

191 Id. at $* 12$.

192 Media Defendants' Brief in Support of Their Motion for Reconsideration, Bartnicki, No. 3:CV94-1201, at 5-6 (M.D. Pa. July 1996) (on file with author).

193 Id. at 6.

194 Id.

195 Id at 7. 
time and effort, the district court denied Brobst's motion and kicked the can down the road. ${ }^{196}$ Brobst asked Judge Kosik to certify the case up to the Third Circuit and he agreed. ${ }^{197}$

While Brobst might have taken the case to trial instead of appealing Judge Kosik's denial of his motion, he acknowledged that there would have been no point in going that route. Apart from the constitutional claim, Brobst said:

[W] didn't have much [in the way of another] defense in this case. They had us dead to rights on what we did. We clearly had broadcast the tape many times. There was no doubt about that. It was pretty hard for us to claim that we didn't know that it had been a surreptitiously recorded tape. $^{198}$

In fact, Brobst said:

[W]e had a settlement agreement with the other side ... that the outcome of the appeal would decide the outcome of the case because there was no sense going to trial .... If we win [on the constitutional issue], we don't have to pay them anything, obviously, and if they win, it was a fixed amount of money that we would pay them. ${ }^{199}$

While the agreement reserved the right of either party to petition the Supreme Court for review, Brobst said neither side really expected the case to go that far. ${ }^{200}$

\section{CIRCUIT COURT: APPLYING INTERMEDIATE SCRUTINY}

On appeal, the parties agreed that no factual issues barred the Third Circuit from resolving the legal issues, ${ }^{201}$ which boiled down to one: Does the First Amendment bar the imposition of liability for publishing truthful information of public significance, where both the acquisition and publication of that information are prohibited by statute and where the publisher was not involved in the unlawful acquisition? ${ }^{202}$

\footnotetext{
196 Bartnicki v. Vopper, 200 F.3d 109, 113 (3rd Cir. 1999), cert. granted, 530 U.S. 1260 (2000).

197 Id.

198 Interview with Donald H. Brobst, supra note 43.

199 Id.

200 Id.

201 Amended Brief of Appellants, supra note 27, at 10, 1998 WL 34082380, at *10.

202 Id. at 2, $1998 \mathrm{WL} 34082380$, at *2.
} 
As might be expected, the appellants continued to rely on the Landmark doctrine and related cases, asserting that the government's interest in the privacy of cellular telephone communications is "significantly less[]" than the interest at stake in Landmark. ${ }^{203}$ The appellants also cited a remarkably similar case in which the U.S. District Court for the Northern District of Texas ruled that the First Amendment protected the press from civil liability for reporting the contents of an illegally recorded telephone conversation of a school board trustee, where the tape had been recorded anonymously, delivered to certain school board members, and played at a public school board meeting. ${ }^{204}$

Perhaps even more interesting was the appellants' attempt to distinguish Cohen by reciting many of the arguments used against the media companies in that case: that the newspapers determined the scope of their own legal obligations by contract, that any restriction on publication was thus self-imposed, and that the newspapers may not have acted lawfully in acquiring the information by reneging on a promise of confidentiality. ${ }^{205}$ The appellants also argued that the impact of enforcing the disclosure provisions of the wiretapping statutes would be far greater than "incidental," as required to impose the Cohen doctrine. ${ }^{206}$

The appellees framed the case as a contest between the Landmark and Cohen principles, although of course they asserted that Cohen applied to this case. ${ }^{207}$ The appellees also found a similar case in which a state trial court had distinguished the Landmark line on two grounds: (1) that the information in those cases had been properly part of the public record, albeit protected by statutory confidentiality; and (2) that the information in the case had been a private conversation, rather than governmental

${ }^{203}$ Id. at 19,1998 WL 34082380 , at *19. One could argue the opposite position, of course: that the government's interest in protecting government speech is lower than its interest in protecting private speech, albeit private speech on a public matter. But see Boettger v. Loverro, 587 A.2d 712, 720-21 (Pa. 1991) ("Thus the legislature intended for the public interest in a free press to supersede the interests of an individual whose private conversation regarding his illegal activities had been lawfully intercepted and lawfully obtained by a newspaper." (footnote omitted)).

204 Amended Brief of Appellants, supra note 27, at 22, 1998 WL 34082380, at $* 22$ (citing Peavy v. New Times, Inc., 976 F. Supp. 532 (N.D. Tex. 1997)). The following year, however, the Peavy decision would be reversed in pertinent part by the United States Court of Appeals for the Fifth Circuit, which applied an intermediate scrutiny test. Peavy v. WFAA-TV, Inc., 221 F.3d 158, 193 (5th Cir. 1999).

205 Amended Brief of Appellants, supra note 27, at 25, 1998 WL 34082380, at *25.

206 Id. at 25-26, 1998 WL 34082380 , at *25-26.

207 Brief of Appellees, supra note 39, at 11, 1998 WL 34083465, at*11. 
records. ${ }^{208}$ That case never mentioned the Cohen doctrine at all, but the appellees devoted a section to amplifying the district court's assertions. ${ }^{209}$

The appellees added some new arguments as well. First, they asserted that the Landmark-related holdings were very narrow and limited to their specific facts. ${ }^{210}$ Specifically, the appellees pointed to the famous footnote eight in Florida Star in which the Court declined to address the question of "unlawfully" acquired information, ${ }^{211}$ suggesting the appellants' reliance on those cases was therefore "misplaced." 212 The appellants, of course, would find that footnote irrelevant, since they committed no unlawful act in acquiring the information.

But even if the strict scrutiny of Landmark controlled, the appellees argued, the wiretapping statutes would pass muster because they were narrowly tailored to protect privacy rights of the highest order. ${ }^{213}$ Drawing on legislative history, the appellees asserted that Congress was aware of and increasingly concerned about the impact of modern communications technology on personal privacy and the law's failure to keep up with that technology. ${ }^{214}$

Appellant Yocum had claimed the status of news-gatherer in his lessthan-coherent brief to the Third Circuit, citing Branzburg v. Hayes for the proposition that he was therefore entitled to First Amendment protection. ${ }^{215}$ The appellees pointed out that, if anything, Branzburg stands for the proposition that news-gatherers enjoy very limited protection, supporting their argument based on the Cohen principle, and that in any case, Yocum's case would succeed or fail on the same grounds as the other appellants' case. $^{216}$

\footnotetext{
208 Id. at 11-13, 1998 WL 34083465, at*11-13 (citing Natoli v. Sullivan, 606 N.Y.S.2d 504 (N.Y. Sup. Ct. 1993), aff'd, 616 N.Y.S.2d 318 (N.Y. App. 1994)).

209 Id. at 17,1998 WL 34083465 , at $* 17$.

$210 I d$. at $20,1998 \mathrm{WL} 34083465$, at $* 20$.

211 Id. at 20-21, 1998 WL 34083465, at *20-21 (citing Florida Star v. B.J.F., 491 U.S. 524, 535 n.8 (1989) (citations omitted), which states, "The Daily Mail principle does not settle the issue whether, in cases where information has been acquired unlawfully by a newspaper or by a source, government may ever punish not only the unlawful acquisition, but the ensuing publication as well. This issue was raised but not definitively resolved in New York Times Co. v. United States and reserved in Landmark Communications. We have no occasion to address it here.").

212 Id. at 21,1998 WL 34083465 , at $* 21$.

213 Id. at 13,1998 WL 34083465 , at *13.

${ }^{214}$ Id. at 15, 1998 WL 34083465 , at $* 15$.

215 Brief on Behalf of Appellee, Jack Yocum at 15, Bartnicki v. Vopper, 200 F.3d 109 (3d Cir. 1998) (No. 98-7156), 1998 WL 34082376, at*15 (citing Branzburg v. Hayes, 408 U.S. 665, 681 (1972)).

216 Brief of Appellees, supra note 39, at 28-29, 1998 WL 34083465, at *28-29.
} 
The only amicus brief in the Third Circuit was filed by the PSEA on behalf of the appellees, and that brief largely echoed the appellees' analysis. It raised-and criticized-another new decision based on similar facts, ${ }^{217}$ and it added another argument analogizing the imposition of civil liability for violation of copyright law and for violation of the wiretap law's disclosure provisions. ${ }^{218}$ Two aspects of the PSEA brief, however, bear mention because of their emphasis in the government's brief and the Third Circuit opinion. Unlike either the district court opinion or the appellees' brief, the PSEA brief put particular emphasis on the wiretap statute's prohibition of "use[s]" of the intercepted materials other than disclosure to show its more general applicability ${ }^{219}$ and characterized the Landmark line as involving "heightened scrutiny" dependent upon the lawfulness of the information's initial acquisition. ${ }^{220}$ Both of these arguments would be substantially amplified in the federal government's brief and addressed, albeit negatively for the most part, in the Third Circuit opinion.

There were no amicus briefs supporting Vopper's position. Brobst does not know why there was no support from other media organizations at this stage - "they certainly would have been aware of the case"-but he acknowledges that he did not solicit any amicus briefs from those organizations. ${ }^{221}$ Given the outcome in the Third Circuit, there was no apparent need for such support.

Following oral argument before the Third Circuit, the United States filed a brief-signed by the Assistant Attorney General for the Justice Department's Civil Division, the U.S. Attorney for the Middle District of Pennsylvania, and two staff appellate attorneys-defending the constitutionality of the wiretap statute's disclosure provision against the appellants' as-applied challenge. ${ }^{222}$ Under federal law, the United States has the right to defend the constitutionality of any federal statute challenged on constitutional grounds. ${ }^{223}$ Although Brobst argued that his "as-applied" challenge did not rise to that level, ${ }^{224}$ the Third Circuit saw the case

\footnotetext{
217 Brief of Pennsylvania State Education Ass'n as Amicus Curiae in Support of PlaintiffsAppellees, supra note 39, at 15 n.7, 1998 WL 34083460, at *15 n.7 (discussing Boehner v. McDermott, 1998 U.S. Dist. LEXIS 11509 (D.D.C. July 27, 1998), which held that "protecting the privacy of electronic communications is not of sufficiently 'high[] order' to justify punishing publication of such communications." (citation omitted)).

218 Id. at 7-8, 1998 WL 34083460 , at *7-8.

219 Id. at 14, 18-19, 1998 WL 34083460 , at *14, *18-19.

$220 I d$. at 16,1998 WL 34083460 , at *16.

221 Interview with Donald H. Brobst, supra note 43.

222 Brief for the United States, supra note 60, at 1, 1998 WL 34082480 , at *1.

22328 U.S.C. § 2403(a) (2006).

224 Interview with Donald H. Brobst, supra note 43.
} 
otherwise and immediately after the argument duly issued a letter inviting the government to file a post-argument brief in the case. ${ }^{225}$ The government's brief points out that its filing was both "at the invitation of the Court" and pursuant to its motion to intervene as of right under the law to defend the constitutionality of the wiretap statute. ${ }^{226}$

The United States can be something of an 800-pound gorilla when it litigates or intervenes in a constitutional challenge. ${ }^{227}$ In an analysis of twenty-four Supreme Court decisions in which the press litigated against the federal government, the press won only eight-or $33.3 \% .{ }^{228}$ In this case, the United States framed the issue less in terms of competing precedents, as the parties had done, than in terms of levels of First Amendment scrutiny to be applied. ${ }^{229}$ The Third Circuit's opinion would track the government's approach.

Following a focused description of the wiretap statute allegedly violated by Vopper, and a synopsis of the proceeding thus far, the government summarized its argument: the First Amendment does not prohibit the application of the wiretap statute's "use prohibitions" to the defendants in this case. ${ }^{230}$ As applied, those provisions are "subject only to intermediate scrutiny under the First Amendment, rather than strict scrutiny, and the statute readily satisfies the requirements of intermediate scrutiny."231 Thus, one argument among others suggested in the PSEA brief had become the foundation for the government's position.

The government argued that the statute's ban on disclosure had to be read as part of a comprehensive ban on all uses of intercepted material; thus, the prohibition did not single out speech for any special burden. ${ }^{232}$ Where that is so, where any burden on speech is merely incidental to the purpose of the law, First Amendment precedent dictates the application of intermediate, rather than strict, scrutiny in determining its constitutionality. ${ }^{233} \mathrm{~A}$ statute satisfies intermediate scrutiny if it furthers an "important" or "substantial" governmental interest (in contrast to strict scrutiny's "compelling" interest); if that interest is unrelated to the

225 Brief for the United States, supra note 60, at 10, 1998 WL 34082480, at *10.

226 Id. at 1, 1998 WL 34082480 , at *1.

227 See Herbert M. Kritzer, The Government Gorilla: Why Does Government Come out Ahead in Appellate Courts?, in IN LITIGATION, Do THE "HAVEs" STILl COME OUT AHEAD? 342 (Herbert M. Kritzer \& Susan Silbey eds., 2003).

228 Easton, Interest Group, supra note 7, at 257-58.

229 Brief for the United States, supra note 60, at 11-12, 1998 WL 34082480, at *11-12.

230 Id. at 11, 1998 WL 34082480 , at *11.

231 Id.

232 Id.

233 Id. at 18-19, 1998 WL 34082480, at *18-19. 
suppression of free expression; and if the incidental restriction on speech is not unnecessarily great (in contrast to strict scrutiny's "no less restrictive alternative available"). ${ }^{234}$

Intermediate scrutiny is also appropriate, the government said, where the prohibitions on the use of illegally intercepted communications are not related to the content of the communications. ${ }^{235}$ Pointing out that the appellants would be free to broadcast the very same tape if acquired lawfully, the government noted that such content-neutral restrictions on speech also require courts to apply intermediate, rather than strict, scrutiny in evaluating their constitutionality. ${ }^{236}$ The restrictions at issue in the Landmark line of cases asserted by the appellants required strict scrutiny because they singled out speech for special burdens and restricted speech because of its content, among other reasons. ${ }^{237}$

Having established the appropriateness of intermediate scrutiny, the government then proceeded to show how the wiretap statute satisfied that standard. The privacy interest to be protected is "manifestly substantial." 238 Moreover, by protecting the confidentiality of communications, the regulations encourage, rather than suppress, free expression. ${ }^{239}$ And, finally, the regulations are tailored carefully enough that they would even satisfy a strict scrutiny standard. ${ }^{240}$

It was a powerful argument, invoking not merely competing analogies, but basic principles of First Amendment analysis; indeed, the Third Circuit adopted just such an approach. Writing for herself and Judge Robert Cowan, Judge Dolores Sloviter rejected the appellants' argument that Landmark was controlling, noting that the question before the court had been expressly reserved by the Supreme Court. ${ }^{241}$ "[W]e will resolve the present controversy not by mechanically applying a test gleaned from Cox and its progeny, but by reviewing First Amendment principles in light of the unique facts and circumstances of this case." 242 But Judge Sloviter also rejected the district court's application of Cohen. Expressing some doubt that the wiretap statute's disclosure provision was a law of general applicability, she pointed out that even if it were, Cohen did not stand for

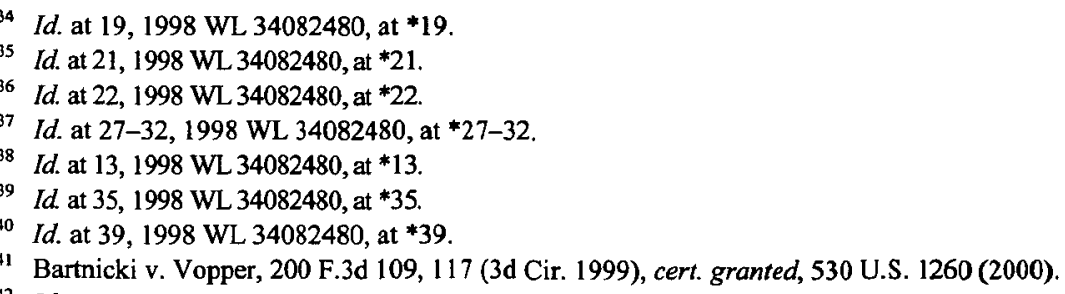


the proposition that laws of general applicability are not subject to First Amendment scrutiny. ${ }^{243}$ Rather, the Supreme Court held only that "'enforcement of such general laws against the press is not subject to stricter scrutiny than would be applied to enforcement against other persons or organizations." "244

As if to emphasize the importance of the United States as a party in this case, Judge Sloviter's analysis all but ignores the original parties and addresses the government's brief directly. Briefly summarizing its argument for intermediate scrutiny, Judge Sloviter proceeded to mock the government's assertion that the statute's ban on "disclosure" is merely an aspect of its ban on "use"- that is, conduct, rather than speech-and thus merited intermediate scrutiny. ${ }^{245}$ "A statute that prohibited the 'use' of evolution theory would surely violate the First Amendment if applied to prohibit the disclosure of Charles Darwin's writings ...."246

On the other hand, the court found the content-neutrality argument more persuasive, based on the Supreme Court's definition of contentneutral restrictions on speech as restrictions that "are justified without reference to the content of the regulated speech."247 Had the Federal Wiretapping Act's only purpose been to prevent the disclosure of private facts, Judge Sloviter suggested, its content-neutrality might be doubted. ${ }^{248}$ But the government did not rely on that justification; rather, she said, insofar as the Act's purpose was to deny the illegal interceptor a market for the "fruits of his labor," it was properly treated as content-neutral and intermediate scrutiny applied. ${ }^{249}$

After reviewing various interpretations of the intermediate scrutiny standard, Judge Sloviter formulated the question before the court as "whether the government has shown that its proffered interest"eliminating the demand for intercepted communications-is sufficiently furthered by imposing liability on the defendants in this case to justify the restrictions on their First Amendment interests. ${ }^{250}$ Finding the connection "indirect at best," the court concluded that "it would be a long stretch indeed" to conclude that imposing damages here would even peripherally

243 Id. at 118.

244 Id. (quoting Cohen v. Cowles Media Co., 501 U.S. 663, 670 (1991)).

245 Id. at 121.

246 Id.

247 Id. at 122 (quoting Renton v. Playtime Theatres, Inc., 475 U.S. 41, 48 (1986)).

248 Id. at 123.

249 Id.

250 Id. at 125. 
promote the government's effort to deter interception. ${ }^{251}$ Since the Act already provides punishment for illegal interception, it would be more effective to enforce those provisions than to impose liability here. ${ }^{252}$

Writing in dissent, District Judge Louis Pollak agreed with the majority's analytical approach to the case, but not with its application. Judge Pollak took issue with the court's assertion that the connection between prohibiting disclosure and preventing interception was "indirect at best," citing a recent decision, Boehner v. McDermott, from the U.S. Court of Appeals for the District of Columbia Circuit to the contrary. ${ }^{253}$ In that case, the court opined that, "[u]nless disclosure is prohibited, there will be an incentive for illegal interceptions; and ... the damage caused ... will be compounded. ${ }^{, 254}$ The majority distinguished Boehner on the ground that the newspapers reporting the intercepted conversation were not defendants in that case, and that defendant McDermott, who provided the tape to the newspapers, knew who had intercepted the conversation and had a political interest in its disclosure. ${ }^{255}$

Following the judgment, Bartnicki and Kane moved for a rehearing by the entire Third Circuit court. According to Brobst, the motion failed by only one vote, suggesting the case was much closer than the panel decision would indicate. ${ }^{256}$

\section{Before THE SuPREME COURT: The PRESS TAKES Notice}

\section{A. The Certiorari Process}

On April 19, 2000, Bartnicki and Kane filed a petition for a writ of certiorari, asking the U.S. Supreme Court to review the Third Circuit decision. ${ }^{257}$ Their original lawyer, Wilkes-Barre attorney Raymond P. Wendolowski, was still listed on the brief supporting their petition, ${ }^{258}$ but with the stakes now that much higher and the venue shifting to Washington, Wendolowski was no longer listed as counsel of record. That responsibility was assumed by Robert $\mathrm{H}$. Chanin and Jeremiah A. Collins of the

251 Id. at 125-26.

252 Id. at 126.

253 Id. at 130 (Pollak, J., dissenting).

254 Id. at 133 (quoting Boehner v. McDermott, 191 F.3d 463, 470 (D.C. Cir. 1999))

255 Id. at $128-29$.

256 Interview with Donald H. Brobst, supra note 43.

257 Petition for Writ of Certiorari, Bartnicki v. Vopper, 532 U.S. 514 (2001) (No. 99-1687), 2000 U.S. S. Ct. Briefs LEXIS 1059.

258 Id. 
Washington, D.C., firm of Bredhoff \& Kaiser, ${ }^{259}$ a thirty-plus-lawyer firm that specialized in representing unions. ${ }^{260}$ Collins had been part of the team that wrote the Pennsylvania State Education Association's amicus brief for the Third Circuit. ${ }^{261}$ The Bredhoff firm was far more experienced in Supreme Court litigation and styles itself "the voice of labor."262

Taking a cue from the dissent below, Bartnicki argued that the Supreme Court should review the case because the Third Circuit decision conflicted with Boehner, setting up a conflict between two circuits that the Supreme Court ought to resolve. ${ }^{263}$ That kind of argument is considered one of the most effective at this stage of the process; if four Justices agree that a conflict exists, the Court will invariably take the case. ${ }^{264}$ Bartnicki also argued that the decision below not only struck down an important provision of a federal statute, but also called into question similar statutes enacted by a majority of the states. ${ }^{265}$ The Third Circuit majority had disparaged that argument as hyperbole when raised by the dissent, pointing out that its "as applied" decision was expressly limited to the facts of this case. ${ }^{266}$

Finally, Bartnicki asserted that the Third Circuit opinion was just wrong as to an important question of constitutional law that had been reserved by the Supreme Court in prior decisions. ${ }^{267}$ The petition asserted that the case provided "an ideal vehicle" for determining whether "a statute that protects privacy interests by making it unlawful for a person to disclose information unlawfully obtained by another violates the First Amendment ...."268 The following week, the United States weighed in, seeking certiorari on its own behalf as an intervenor in the case, with Solicitor General Seth P. Waxman listed as counsel of record. ${ }^{269}$ The government's argument closely paralleled Bartnicki's.

\footnotetext{
259 Id.

${ }^{260}$ See Welcome to Bredhoff \& Kaiser, P.L.L.C., BREDHOFF \& KAISER P.L.L.C., http://www.bredhoff.com (last visited Nov. 23, 2011).

261 See supra notes 217-20 and accompanying text.

262 See Welcome to Bredhoff \& Kaiser, P.L.L.C., supra note 260.

263 Petition for Writ of Certiorari, supra note 257, at 12, 2000 U.S. S. Ct. Briefs LEXIS 1059, at *20-21.

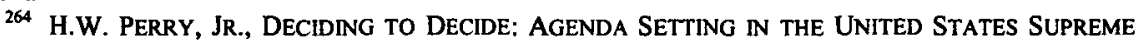
COURT 127-28 (1991).

${ }^{265}$ Petition for Writ of Certiorari, supra note 257, at 14-15, 2000 U.S. S. Ct. Briefs LEXIS 1059, at $\bullet 24-25$.

266 Bartnicki v. Vopper, 200 F.3d 109, 128 (3d Cir. 1999).

267 Petition for Writ of Certiorari, supra note 257, at 15-16, 2000 U.S. S. Ct. Briefs LEXIS 1059, at *25-26.

269 Petition for Writ of Certiorari, Bartnicki v. Vopper, 532 U.S. 514 (2001) (No. 99-1728), 2000 U.S. S. Ct. Briefs LEXIS 1063.
} 
When Vopper's brief in opposition to certiorari was filed on May 30, the radio host was also represented by new counsel. According to Donald Brobst, Vopper's employer-Keymarket of NEPA, the owner of radio station WILK - had been acquired by Sinclair Broadcast Group sometime during the pendency of the case. ${ }^{270}$ While Sinclair initially kept Brobst on as outside counsel, he had what he describes as a "falling out with in-house counsel for Sinclair that had nothing to do with this case,"271 although part of the problem involved Fred Vopper.

In one case, Brobst said, Sinclair wanted him to defend Vopper in a case brought by a district attorney who also happened to be running for judicial office. ${ }^{272}$ One of the Rosenn, Jenkins \& Greenwald (RJG) partners was campaign treasurer, raising a potential conflict of interest for any lawyer in the firm. ${ }^{273}$ Another case involved Vopper challenging the integrity of two judges before whom RJG had other cases pending. ${ }^{274}$ Sinclair's in-house counsel was "not happy about that," Brobst said, and the relationship started to go downhill. ${ }^{275}$ After another, unrelated dispute arose, they "decided to have a parting of the ways on all cases," ${ }^{276}$ and Brobst lost the chance to take Bartnicki v. Vopper to the U.S. Supreme Court.

Instead, that honor went to Lee Levine, even then a major star in the media law firmament, having founded his own Washington law firmLevine, Sullivan \& Koch, L.L.P.—only three years earlier. ${ }^{277}$ This would be Levine's second argument before the Supreme Court; he had previously represented the newspaper defendant in Harte-Hanks Communications, Inc.

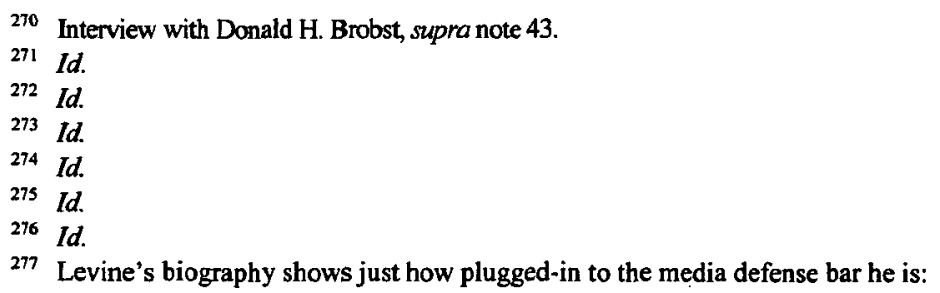

Mr. Levine has served as Chair of the American Bar Association's Forum on Communications Law, as President of the Defense Counsel Section of the Media Law Resource Center, as Chair of both the Media Law Committee and the Publications Committee of the District of Columbia Bar, . . . and as an ABA Advisor to the Uniform Defamation Act Drafting Committee of the Conference of Commissioners on Uniform State Laws. He currently serves as co-chair of the Practicing Law Institute's annual Communications Law conference, as a member of the Board of Directors of Fred Friendly Seminars, Inc.[.] . . . and as a member of the Advisory Board of the Bureau of National Affairs' Media Law Reporter.

Lee Levine: Biography, Levine, SullivaN, KoCH \& SCHULTz, L.L.P., http://www.pli.edu/Content. aspx?dsNav=Rpp:1,N:4294934230-168\&ID=PE327995 (last visited Nov. 23, 2011). 
v. Connaughton. ${ }^{278}$ Levine also taught media law at Georgetown University Law Center and co-authored a major treatise on newsgathering. ${ }^{279}$ Brobst recalls that he had some initial contact with the new litigation team-"I sent them everything they wanted"280 - then bowed out of the case.

Levine's brief in opposition to certiorari rejected all of the reasons for judicial review raised in the Bartnicki and United States petitions. The Third Circuit decision "constitutes an unremarkable assessment of whether the imposition of civil liability" on the media defendants under the Wiretap Act "survives intermediate scrutiny . . .."281 "In making this fact-bound assessment," the brief asserted, "the Third Circuit expressly declined to address the 'important question of constitutional law' referenced by Petitioners, 'struck down' no provision of either statute, and applied the same standard of First Amendment scrutiny embraced by the majority of the District of Columbia Circuit in Boehner."282

Those arguments were echoed in respondent Yocum's brief in opposition, ${ }^{283}$ but successfully rebutted in reply briefs from Bartnicki ${ }^{284}$ and the United States. ${ }^{285}$ On June 26, 2000, the U.S. Supreme Court granted the petition for certiorari. ${ }^{286}$

In contrast to the Third Circuit proceeding, amicus briefs began flowing into the Court in September; three of them were filed by litigants in cases representing nearly identical issues. Representative John Boehner (R-Ohio), whose victory in the D.C. Circuit had prompted Bartnicki's "split in the circuits" argument, argued for petitioners that "there is no First Amendment right to distribute someone else's pilfered speech." ${ }^{287}$ Boehner's opponent, Representative James McDermott (D-Washington), whose petition for certiorari was still pending at the time, argued that disclosure provisions of the wiretap statute should be subject to strict scrutiny. ${ }^{288}$ WFAA-TV of

\footnotetext{
278491 U.S. 657,659 (1989).

279 C. THOMAS DIENES, LEE LEVINE \& ROBERT C. LiND, NEWSGATHERING AND THE LAW (3d ed. 2005).

280 Interview with Donald H. Brobst, supra note 43.

281 Brief in Opposition at 4, Bartnicki v. Vopper, 532 U.S. 514 (2001) (Nos. 99-1687 \& 99-1728), 2000 U.S.

S. Ct. Briefs LEXIS 1060 at *7.

282 Id. at 4, 2000 U.S. S. Ct. Briefs LEXIS 1060, at *7-8.

283 Id. at 5-6, 2000 U.S. S. Ct. Briefs LEXIS 1060, at *9-10.

284 Reply Brief for Petitioners, Bartnicki, 532 U.S. 514 (No. 99-1687), 2000 U.S. S. Ct. Briefs LEXIS 1062.

285 Reply Brief for the United States, Bartnicki, 532 U.S. 514 (No. 99-1687), 2000 U.S. S. Ct. Briefs LEXIS 1064.

286 Bartnicki v. Vopper, 200 F.3d 109 (3d Cir. 1999), cert. granted, 530 U.S. 1260 (2000).

287 Brief of Amicus Curiae Representative John A. Boehner in Support of Petitioners at 3, Bartnicki, 532 U.S. 514 (Nos. 99-1687 \& 99-1728), 2000 U.S. S. Ct. Briefs LEXIS 492, at *4.

${ }^{288}$ Brief Amicus Curiae of Representative James A. McDermott in Support of Respondents at 2-4,
} 
Dallas, Texas, which was poised to file its own petition seeking review of an adverse Fifth Circuit decision, ${ }^{289}$ sought to push the Court to the ultimate rule-further than any other participant:

This case should be decided according to a simple, bright line rule: if a journalist breaks the law to obtain information, she is subject to whatever generally applicable legal penalties may be triggered by the act of misappropriation. However the journalist has obtained information, she may be punished only for any impropriety in obtaining it, and not for publishing it, absent a countervailing governmental interest of the highest order. $^{290}$

Only one other amicus brief was filed on behalf of Bartnicki and Kane; the cellular telephone industry argued that ensuring the privacy of wireless communications would further federal policies favoring the free speech of cell phone subscribers and encouraging the industry's growth. ${ }^{291}$ In addition to McDermott's and WFAA-TV's briefs, four briefs were filed on behalf of the media defendants. Both the American Civil Liberties Union and The Liberty Project argued that strict scrutiny, rather than intermediate scrutiny, was the appropriate standard to apply. ${ }^{292}$ And Wall Street Journal owner Dow Jones \& Co., with a brief signed by Supreme Court veteran Theodore Olson, called for "straightforward application of the Daily Mail test"293 essentially Brobst's argument in the district and circuit courts. ${ }^{294}$

But the media's principal amicus brief, with Floyd Abrams as counsel of record, was filed on behalf of more than twenty media entities and organizations, including newspaper and magazine publishers, television and cable networks, and journalism trade and professional associations. ${ }^{295}$ The list of attorneys representing the amici reads like a "Who's Who" of media

Bartnicki, 532 U.S. 514 (Nos. 99-1687 \& 99-1728), 2000 U.S. S. Ct. Briefs LEXIS 548, at *6-9.

289 Peavy v. WFAA-TV, Inc., 221 F.3d 158 (5th Cir. 2000).

290 Brief of Amici Curiae WFAA-TV and Robert Riggs in Support of Respondents at 4, Barmicki, 532 U.S. 514 (Nos. 99-1687 \& 99-1728), 2000 U.S. S. Ct. Briefs LEXIS 578, at *6.

291 Brief Amicus Curiae of the Cellular Telecommunications Industry Association in Support of Petitioners at 4-9, Bartnicki, 532 U.S. 514 (Nos. 99-1687 \& 99-1728), 2000 U.S. S. Ct. Briefs LEXIS 493 , at $* 8-16$.

292 Brief Amicus Curiae of the ACLU and the ACLU of Pennsylvania in Support of Respondents at 5, Bartnicki, 532 U.S. 514 (Nos. 99-1687 \& 99-1728), 2000 U.S. S. Ct. Briefs LEXIS 577, at*10; Brief of Amicus Curiae of The Liberty Project in Support of Respondents at 5, Bartnicki, 532 U.S. 514 (Nos. 99-1687 \& 99-1728), 2000 U.S. S. Ct. Briefs LEXIS 547, at *8-9.

293 Brief Amicus Curiae of Dow Jones \& Co., Inc. in Support of Respondents at 5, Bartnicki, 532 U.S. 514 (Nos. 99-1687 \& 99-1728), 2000 U.S. S. Ct. Briefs LEXIS 546, at *11.

294 Id.

295 Brief Amici Curiae of Media Entities and Organizations in Support of Respondents, Bartnicki, 532 U.S. 514 (Nos. 99-1687 \& 99-1728), 2000 U.S. S. Ct. Briefs LEXIS 579. 
law. It is impossible to say with any certainty how much influence any brief may have had on the Court, but the similarity between the media. entities' brief and the Court's majority opinion is striking.

\section{B. The Amicus Brief Process}

Before discussing the content of the various briefs filed with the Court, a brief digression is warranted to explore the process through which the media bar participates as amici curiae in Supreme Court litigation today. According to Lucy Dalglish, the Executive Director of the Reporters Committee on Freedom of the Press (RCFP), the process is an informal one ${ }^{296}$ For example, the RCFP first got involved in the Bartnicki case in June $2000 .{ }^{297}$ Legal defense director, Gregg Leslie, had put out an email message to a number of prominent media lawyers, among them Laura Handman of Davis Wright Tremaine, Bruce Sanford of Baker Hostetler, and Lee Levine, asking:

Does anyone know of an amicus effort underway in Bartnicki? We've always been available to write one, or at least coordinate efforts, but I assume there will be big companies willing to pay a firm for a brief now that it's before the high court. If you have any information that you're available to share, I'd be happy to hear it. ${ }^{298}$

Soon after, Adam Liptak, then in-house counsel for the New York Times, now its Supreme Court reporter, replied, "Gregg, yes, there is an amicus effort. The Times and others have asked Floyd Abrams to prepare a brief and I'm sure the Reporters Committee will be welcome [to join the brief] on the usual terms." ${ }^{, 299}$ By "usual terms," Liptak was referring to the informal arrangement through which signatories to the brief help the lead organization (here, the Times) pay for it. The RCFP and other nonprofits usually ride along for free, and when the RCFP lawyers write the brief, all others in the media world are invited to join at no charge. ${ }^{300}$ Typically, however, the private entities pay for the privilege. ${ }^{301}$ According to Dalglish, the cost can vary. ${ }^{302}$

296 Interview with Lucy Dalglish, Exec. Dir. of Reporters Comm., Freedom of the Press (June 15, 2010) (recording on file with author).

297 Id.

298 Id.

299 Id.

300 Id.

301 Id.

302 Id. 
"It depends on how much time it's going to take, how many people [the lawyers] think need to do it. They've been cutting their rates a little bit lately. In the summertime, they want to do it more because they can use their summer associates if they have them. I'd say anywhere from $\$ 10,000$ to $\$ 30,000$ these days is what it would cost." ${ }^{303}$ Once the cost is established, the lead organization would begin "trolling" for signers. ${ }^{304}$ If, for example, the sign-on price is $\$ 1,500$, Dalglish said, "[I]f you get a whole pile of folks signing on, you're doing OK, but if you only get five, you've rolled the dice and you've lost." ${ }^{\prime 305}$

As to the content of the briefs, Dalglish said amici first figure out what the party they are supporting has already argued, then identify other issues that the party did not have room for. ${ }^{306}$ "Usually, what we try to do is present a national perspective, do some public policy stuff, or brief an issue that the parties would have loved to have briefed if they had time or space. Sometimes they will ask you specifically, could you do this issue. ${ }^{307}$ Other times, amici will suggest the focus of the brief. In either event, amici will try to avoid simply repeating the party's arguments. "No court wants to put up with that," Dalglish said. ${ }^{308}$ "I just have no interest in parroting back the party's brief.",

The relationship between amici and the parties varies somewhat depending upon the court hearing the case. Under Supreme Court rules, ${ }^{310}$ and throughout the federal system, ${ }^{311}$ all parties must consent to the filing of an amicus brief; where consent is withheld, amici may petition the court to receive the brief anyway. Thus, there is always some communication between the amici and the party they are supporting. Dalglish described the typical process: "You let them know you're going to do it, and they'll say 'Hey! Yeah, that would be great-wonderful. We'll sign the letter and give it to you." 312 On the other hand, the Supreme Court rules require amici to disclose whether counsel for a party had a hand in writing the brief or paying for it. ${ }^{313}$

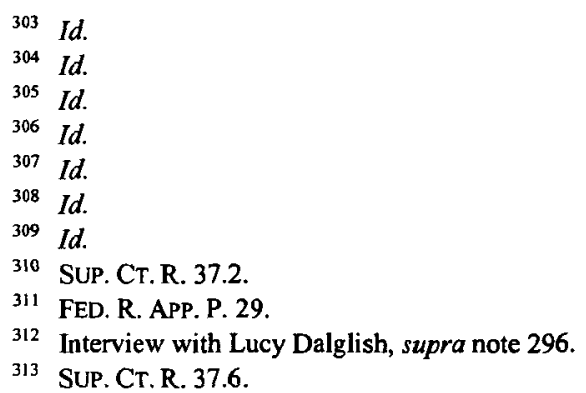


Still, the parties often ignite the amicus process. If the case gets to the Supreme Court, it has already been percolating through the media defense bar. By the time they have won or lost in the appellate courts, the parties will have talked about it in one of several forums where members of the media defense bar get together. Among these are the Practising Law Institute's annual Communications Law Conference, founded and managed for some thirty-five years by James Goodale, now conducted by Lee Levine as Communications Law in the Digital Age; $;^{314}$ the biennial conference and other meetings of the Media Law Resource Center, formerly the Libel Defense Resource Center, also based in New York; ${ }^{315}$ the annual conference and various workshops of the American Bar Association's Forum on Communications Law; ${ }^{316}$ and the annual Media and the Law Seminar at the University of Kansas. ${ }^{317}$

One of the most important of these forums is the District of Columbia Bar Association's Media Law Committee, which meets informally once a month for lunch at the offices of one of the participating law firms. ${ }^{318}$ The meetings were started by Davis Wright's Laura Handman, who chaired them for two years. ${ }^{319}$ Lee Levine has also chaired the meetings, as have the RCFP's Gregg Leslie, Covington \& Burling's Kurt Wimmer, and Holland $\&$ Knight's Chuck Tobin. ${ }^{320}$ Lawyers from Washington, D.C., and often New York, come to talk about their strategy in cases that have been argued or to preview upcoming cases. ${ }^{321}$ They are not, Dalglish said, strategy sessions to plan how the bar might get involved. ${ }^{322}$

That happens more informally, Dalglish said. ${ }^{323}$ Frequently, the New York Times takes the lead, or the Washington Post, or the Associated Press. "They tend to sort of rotate. ... Sometimes it's the individual lawyer [who

\footnotetext{
314 Floyd Abrams, James Goodale Passes the Torch at PLI Communications Law Conference, MLRC MEDia L. LETTER (Media Law Res. Ctr., New York, N.Y.), Nov. 2007, at 6, available at http://www.jamesgoodale.net/images/MLRC_PLI_Letter.pdf; see also Seminar, Communications Law in the Digital Age 2010, PraCtISING L. INST. (Nov. 26, 2010), http://www.pli.edu/Content.aspx?dsNav=Rpp:1,N:4294963947-167\&ID=60604.

${ }^{315}$ See About MLRC, MEDIA L. REs. CTR., http://www.medialaw.org/Template.cfm?Section= About_MLRC\&Template $=/$ ContentManagement/HTMLDisplay.cfm\&ContentID $=8828$ (last visited Nov. 23,2011 ).

${ }^{316}$ See About Us, AM. BAR Ass'N, http://www.americanbar.org/groups/communications_law/ about_us.html (last visited Nov. 23, 2011).

${ }^{317} \mathrm{See}$ KU CONTINUING EDUC., http://www.continuinged.ku.edu/programs/media_law/ (last modified Nov. 4, 2011).

${ }_{318}$ Interview with Lucy Dalglish, supra note 296.

319 Id.

320 Id.

321 Id.

${ }^{322}$ Id.

323 Id.
} 
is interested in a particular case]. ... Sometimes it's geographic. Sometimes they have a similar case percolating and they want to jump on it. . . . Sometimes it's driven by who's interested in covering a story." says the informal system works so well because the bar is so small. "It's a very small group of people. Very tight knit. . . . So you're seeing these people frequently, and you're staying on top of things frequently. . . . Everybody knows everybody else." 325

As for the Reporters Committee itself, Dalglish noted that she has former fellows working all over the country. "I will hire a fellow [who] will spend a year working here. I will work [at] getting him a job at one of the firms. ... And then some of those folks end up going in-house because they don't like the law firm atmosphere. Right now, I've got former fellows inhouse at the Washington Post and National Public Radio. . . . [In] the last couple of years, my folks have been snatched up by the government . . . as FOIA [Freedom of Information Act] officers. $" 326$

Dalglish said RCFP used to be a lot more involved in direct litigation, pointing out that "the last time we were actually actively involved as a party was . . . when we went in with the Center for National Security Studies . . . to get a list of the 1,500 or so foreign nationals who were snatched off the streets and put in detention centers" after Sept. 11, 2001. ${ }^{327}$ The U.S. Court of Appeals for the District of Columbia ultimately reversed an initially favorable decision by the district court. ${ }^{328}$ During the past decade or so, since Dalglish has been executive director, the RCFP has been doing more amicus briefs. $^{329}$

"We look for cases that will have the potential to have an impact on what journalists are able to do, either in their home state or on the federal level, and that can be in regards to an open meetings or open records violation." 330 "It can be getting involved in a libel case, or certainly in a reporter's privilege case. We tend not to get involved at the trial level," Dalglish said, citing lack of need, cost, and the potential to irritate trial judges. 331 "That's not to say we haven't done it, but at the trial court level we usually try to get involved if it is an issue that can be of great relevance

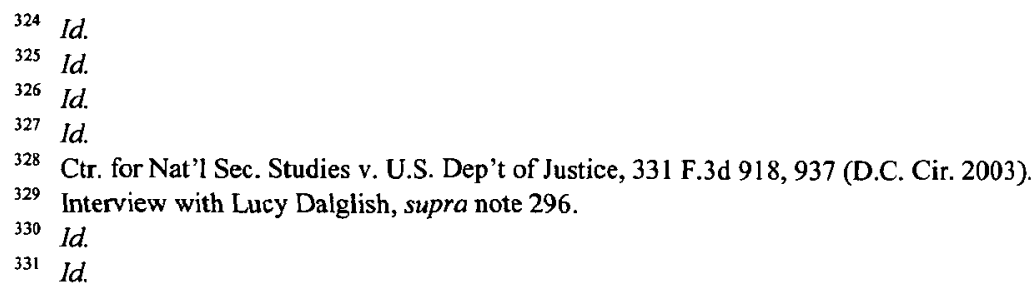


to the media, but neither of the parties is a media entity."332 Expanding on the RFCP's role, she added, "We may look at some of the pleadings and decide that there may be a benefit to having a media lawyer write the brief and raise some issues that perhaps [another lawyer would see differently]."333

Dalglish said she also tries "not to get involved at the cert. petition stage at the U.S. Supreme Court, unless there's a compelling reason to," like if it's "a case we really, really want them to take, or a case that we know they're going to take and we want to get the issue teed up right away. And, quite honestly, there's one other very important factor, and that has to do with journalism politics. We want to stake our territory. We want to do a brief and show that the Reporters Committee is on top of it.",334

"If [the case is] at an intermediate court level at the federal level, we're almost certainly going to get involved if it involves anything having to do with the media. Sometimes, they slip by us." ${ }^{335}$ In Bartnicki, where no media amicus briefs were filed in the Third Circuit proceeding, Dalglish recalls that other, similar cases were being "teed up" at about the same time. 336 "Hopefully, we've gotten a little bit better at spotting them on the circuit level, but that doesn't mean we always catch them. . . . Certainly, when the Supreme Court took [Bartnicki], we got involved in force."337

\section{The Briefs}

Most of the arguments in the parties' briefs had been auditioned below. Bartnicki and Kane began their argument for reversing the Third Circuit opinion by urging the Court to adopt an intermediate scrutiny standard-a point on which the Third Circuit agreed. ${ }^{338}$ It next walked the Court through an unremarkable analysis to show that the statutes, as applied, satisfy that standard. ${ }^{339}$ The federal government's brief made essentially the same

332 Id.

333 Id.

334 Id.

335 Id.

336 Specifically, Dalglish was referring to Boehner v. McDermott, 191 F.3d 463 (D.C. Cir. 1999) (upholding the disclosure provisions of the wiretap act where the defendant congressman allegedly knew the interceptors and promised them immunity for their illegal conduct) and Peavy v. WFAA-TV, Inc., 221 F.3d 158 (5th Cir. 2000) (upholding the disclosure provisions where the defendant television station not only knew the interceptions were illegal, but participated in their acquisition).

337 Interview with Lucy Dalglish, supra note 296.

338 Brief for Petitioners Gloria Bartnicki and Anthony F. Kane, Jr. at 13, Bartnicki v. Vopper, 532 U.S. 514 (2001) (Nos. 99-1687 \& 99-1728), 2000 U.S. S. Ct. Briefs LEXIS 494, at *26.

339 See id. at 12-16, 2000 U.S. S. Ct. Briefs LEXIS 494, at $* 25-32$. 
case. ${ }^{340}$ For Vopper and the other media defendants, Levine argued that the case required application of the Daily Mail principle, another way of arguing for strict scrutiny, but he added that the statutes in question would not even satisfy intermediate scrutiny. ${ }^{341}$ Yocum, who had by now retained his own Supreme Court specialist, Thomas C. Goldstein, made the same arguments in reverse order. ${ }^{342}$ The petitioners' reply briefs broke little new ground. ${ }^{343}$

Floyd Abrams's amicus brief for the "media entities" also argued that the Third Circuit opinion should be affirmed on a Florida Star (i.e., Landmark or Daily Mail) analysis, ${ }^{344}$ noting only in a footnote that the statute would fail intermediate scrutiny as well. ${ }^{345}$ But Abrams prefaced his legal argument with a much broader policy appeal:

From the time individuals first consider becoming journalists, two principles are drilled into them. ...

The first is that telling the truth about matters of public interest is what journalism, at its best, is all about. .. . [J]ournalists who read opinions of this Court find unsurprising this Court's repeated references to "the overarching public interest, secured by the Constitution, in the dissemination of truth." That public interest is directly imperiled in this case.

So is the journalistic norm that in the course of gathering news, journalists should affirmatively seek the truth from those who have it ....

...

For journalists, then, the notion that liability may be imposed upon them for doing nothing more or less than reporting truthfully about newsworthy

340 Brief for the United States at 10-15, Bartnicki, 532 U.S. 514 (Nos. 99-1687 \& 99-1728), 2000 U.S. S. Ct. Briefs LEXIS 491, at*22-31.

${ }^{341}$ Brief for Respondents Frederick W. Vopper, Keymarket of NEPA, Inc. and Lackazerne, Inc. at 13-17, Bartnicki, 532 U.S. 514 (Nos. 99-1687 \& 99-1728), 2000 U.S. S. Ct. Briefs LEXIS 581, at*29 39.

342 Brief for Respondent Jack Yocum at 6-10, Bartnicki, 532 U.S. 514 (Nos. 99-1687 \& 99-1728), 2000 U.S. S. Ct. Briefs LEXIS 580, at*15-23.

${ }^{343}$ See Reply Brief for Petitioners Gloria Bartnicki and Anthony F. Kane, Jr., Bartnicki, 532 U.S. 514 (Nos. 99-1687 \& 99-1728), 2000 U.S. S. Ct. Briefs LEXIS 659; Reply Brief for the United States, Bartnicki, 532 U.S. 514 (Nos. 99-1687 \& 99-1728), 2000 U.S. S. Ct. Briefs LEXIS 658.

344 Brief Amici Curiae of Media Entities and Organizations in Support of Respondents, supra note 295, at 6-9, 2000 U.S. S. Ct. Briefs LEXIS 579, at*15-19.

${ }^{345}$ Id. at 27 n. 34,2000 U.S. S. Ct. Briefs LEXIS 579, at *48 n.34. 
events is deeply disturbing. ${ }^{346}$

Although the Third Circuit had viewed the government's interest in deterring unlawful interceptions as the most, albeit insufficiently, compelling justification for the statute's non-disclosure provisions, Abrams focused on the privacy interest. ${ }^{347}$ The privacy interests held insufficient in the Florida Star line of cases, he said, were no less powerful than the privacy interests in this case. ${ }^{348}$ Abrams asked, "[W]hy, after all, is the right of a rape victim not to have her name disclosed less significant than that of a union official not to have a telephone call disclosed in which he threatened to engage in criminal conduct?" 349

Abrams moved on to reject the notion, advanced by Bartnicki, that the Florida Star line of cases was limited to content-based restrictions on speech and, thus, not applicable to the content-neutral disclosure restrictions of the wiretap laws. ${ }^{350}$ Rather, he said, that line of authority is firmly grounded in the public interest in truth-telling. ${ }^{351}$ Abrams also made the seemingly unnecessary argument that the media defendants acted lawfully in obtaining the tape, ${ }^{352}$ then returned to balance of privacy and truth-telling interests. ${ }^{353}$ In the very last paragraph of the argument, almost as an afterthought, Abrams struck the precise theme that would dominate the Supreme Court's opinion:

We offer the final thought that there is, in the end, a certain lack of equivalence between the First Amendment interests at stake here and the privacy interests that underlie the wiretapping statute. Both are important but only one is in the written Constitution. It should not be too late to assert that when the First Amendment's protection of truth-telling is pitted against an interest that was only first identified just over a century ago, some deference should be given to the Framer's expressed intentions.

Oral arguments were held on December 5, 2000. ${ }^{355}$ Collins led off for petitioners Bartnicki and Kane, and his responses to the Court's questions

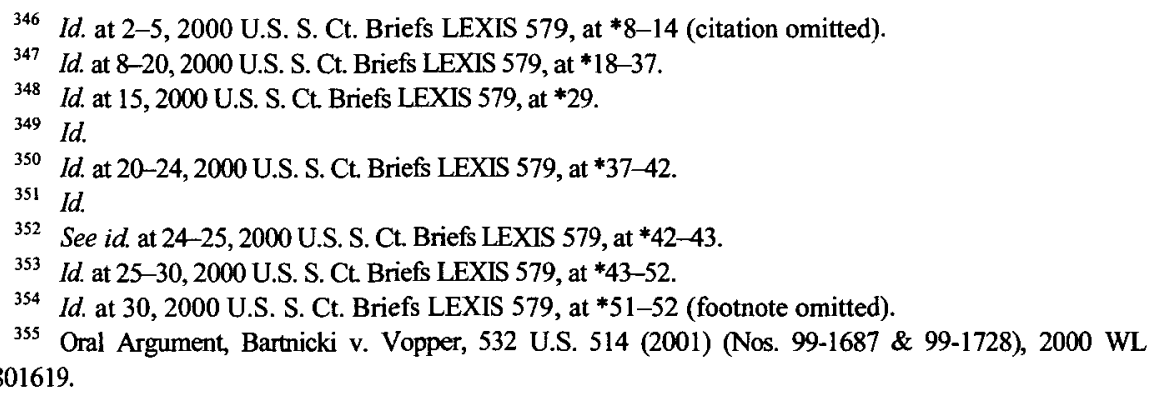


emphasized the content-neutrality of the anti-disclosure statutes. ${ }^{356}$ When a content-neutral statutory regime that protects important governmental interests would be harmed by disclosure, he said, "we believe and we have argued that that in essence exhausts the First Amendment concerns . . .."357 Solicitor General Waxman, who argued next, contradicted Collins's "suggestion" that no heightened scrutiny is required here. ${ }^{358}$ "That's not our position," he said; "we submit that the appropriate level of scrutiny is intermediate-level scrutiny ...., .,359

Justice Anthony Kennedy and others expressed concern that the statutes created a class of speech that was forever tainted and could not be repeated by anyone. ${ }^{360}$ Waxman countered that once the speech became publicly known, the statutes would no longer apply. ${ }^{361}$ Thus a newspaper was free to comment on the conversation once Vopper broadcast it. ${ }^{362} \mathrm{He}$ also defended the argument that enforcing the anti-disclosure statutes would deter unlawful interceptions. ${ }^{363}$

Levine began his oral argument by calling attention to the threat contained in the intercepted conversation, which led to a distracting colloquy with Justice John Paul Stevens and others about whether he wanted to win his case on that narrow ground or on principle. ${ }^{364}$ Insisting, as he was bound to do, that he would take the win "any way I can get it," Levine focused on the Daily Mail principle as the proper basis for decision. ${ }^{365}$ Levine denied that the statutes' content neutrality would require an intermediate scrutiny analysis, but asserted that the anti-disclosure provisions would not survive even that modest test. ${ }^{366}$

The balance of Levine's time was taken up with an inconclusive discussion of the statutes' deterrence value, and that was where Yocum's counsel, Thomas Goldstein, began his appearance before the Court. ${ }^{367}$ "Even if [the anti-disclosure provisions] add some deterrent, that prohibition is too crude a weapon, effectively a thermonuclear bomb of

Id., 2000 WL 1801619, at *9-15.

${ }^{357}$ Id, $2000 \mathrm{WL} 1801619$, at *11.

${ }^{358}$ Id., $2000 \mathrm{WL} 1801619$, at *16-19.

359 Id., 2000 WL 1801619 , at *16-17.

${ }^{360}$ Id., $2000 \mathrm{WL} 1801619$, at $* 21$.

${ }^{361} \mathrm{Id}$.

${ }^{362}$ See id., $2000 \mathrm{WL} 1801619$, at *21-23.

${ }^{363} I d ., 2000$ WL 1801619 , at *22-23.

364 Id., 2000 WL 1801619 , at *25-27.

365 Id., 2000 WL 1801619, at *27.

366 Id., $2000 \mathrm{WL} 1801619$, at *30.

${ }^{367}$ Id., $2000 \mathrm{WL} 1801619$, at *27-38. 
sorts to be sustained in the sensitive area of . . . free speech." ${ }^{368}$ Goldstein endorsed the Third Circuit's intermediate scrutiny approach, ${ }^{369}$ and took issue with Waxman's assertion that the statutes' effectively immunized down-stream commentary on the intercepted conversation. ${ }^{370}$ Waxman, in a brief rebuttal, defended the deterrence argument and distinguished the Daily Mail line of cases. ${ }^{371}$ At 12:03 p.m., Chief Justice Rehnquist declared the case submitted. ${ }^{372}$

\section{THE SUPREME COURT OPINION: AD HOC BALANCING}

In his opinion for the Court, delivered May 21, 2001, Justice Stevens adopted the frame that Abrams had urged-a conflict between the "full and free dissemination of information concerning public issues" and "individual privacy." 373 Justice Stevens's formulation of the issue, however, labeled both interests "of the highest order," and he appeared to accept the idea, advanced by the petitioners, that the disclosure provisions of the statute would "foster[] private speech." ${ }^{374}$ Nevertheless, Justice Stevens promptly declared that the disclosures made in this case were protected by the First Amendment. ${ }^{375}$

The opinion that followed was unusually disjointed, shifting from doctrinal analysis, to interrogation of precedents, and ultimately to ad hoc balancing. Justice Stevens began by accepting the petitioners' characterization of the disclosure provisions as a "content-neutral law of general applicability. ${ }^{, 376}$ Unlike the trial court, however, he did not find that dispositive. "On the other hand," he said, "the naked prohibition against disclosures is fairly characterized as a regulation of pure speech,"377 as if that somehow negated or counterbalanced the general applicability doctrine as applied in Cohen v. Cowles Media. ${ }^{378}$

Seeming to reach a dead end with this doctrinal inquiry, Justice Stevens shifted abruptly to interrogating precedent. ${ }^{379}$ Here, too, the analysis ended

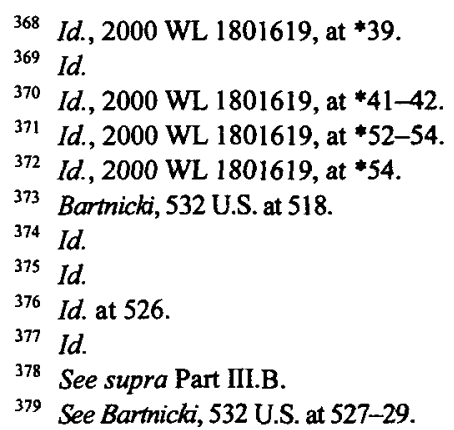


without resolution, with Justice Stevens pointing out that neither the Pentagon Papers case, ${ }^{380}$ nor the Landmark-Daily Mail-Florida Star line of cases, ${ }^{381}$ resolved the question presented here. ${ }^{382}$ The only lesson Justice Stevens seemed to take from these precedents was the need to balance, on the facts of this case, the interests served by the law against its restrictions on speech.

Like the Third Circuit, Justice Stevens ultimately rejected the government's asserted interest in deterring interception of private conversations as a bona fide interest of the "highest order." 383 Unlike the Third Circuit, he found the privacy interest compromised here to be a "valid independent justification for prohibiting such disclosures . . . . "384 Nevertheless, those privacy interests had to "give way when balanced against the interest in publishing matters of public importance." principally on libel cases for support, Justice Stevens held that a "stranger's illegal conduct does not suffice to remove the First Amendment shield from speech about a matter of public concern.

In a concurring opinion, joined by Justice Sandra Day O'Connor, Justice Stephen Breyer emphasized the narrowness of the Court's holding. ${ }^{387}$ Justice Breyer, well known for his ad hoc balancing approach to First Amendment cases, ${ }^{388}$ cautioned that this case was decided on the facts that the broadcasters acted lawfully in obtaining the information and the information involved the threat of physical harm to others. ${ }^{389}$ It did not signal a "significantly broader constitutional immunity for the media," he warned. 390

Justice Breyer asserted that concepts like "strict scrutiny" are inappropriate to resolve competing interests. ${ }^{391} \mathrm{He}$ also seemed to put far more value in the deterrent effect of the anti-disclosure provisions than either the majority or Third Circuit opinion. ${ }^{392}$ But on these facts, Justice

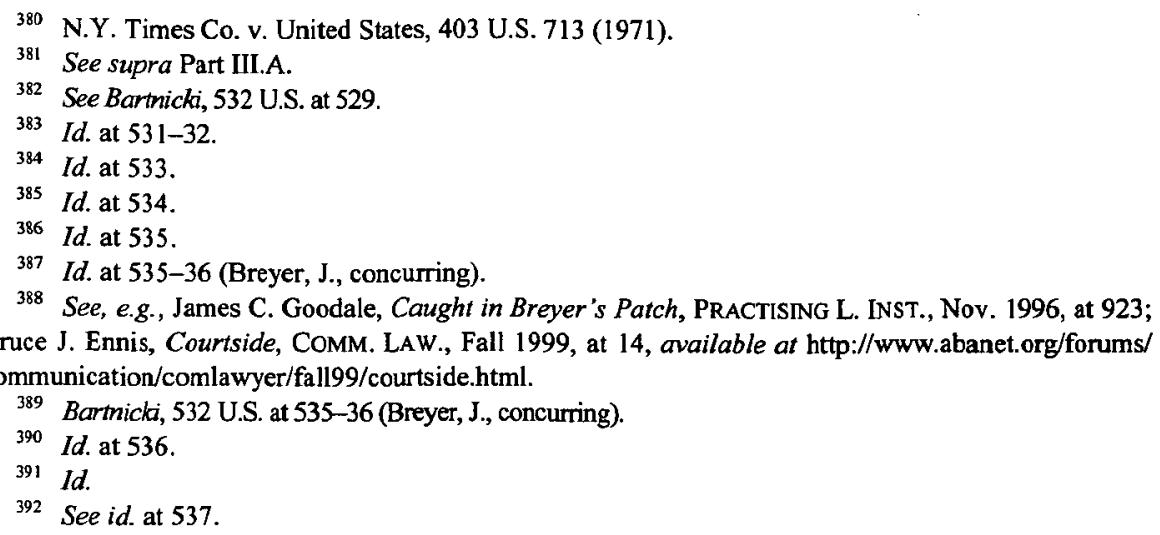


Breyer said, the speakers had no "legitimate" interest in the privacy of a threat to harm others- even where the danger had passed. ${ }^{393}$ Justice Breyer also emphasized that Bartnicki and Kane were "limited public figures" with a "lesser" interest in privacy. ${ }^{394}$

Justice Breyer concluded that the Court did "not create a 'public interest' exception that swallows up the statutes' privacy-protecting general rule." ${ }^{395}$ Rather, he said, these speakers' privacy expectations were unusually low, while the public interest in "defeating those expectations" was unusually high. ${ }^{396}$ And thus, he "would not extend that holding beyond these present circumstances.",397

Of course, the dissenters would not have gone even that far. Writing for Justices Antonin Scalia and Clarence Thomas, Chief Justice William Rehnquist correctly identified the contradiction in Justice Stevens's acknowledgment that the anti-disclosure provisions were "content-neutral law[s] of general applicability" and the outcome that Justice Stevens ultimately reached. ${ }^{398}$ But he inexplicably mischaracterized Justice Stevens's analytical approach as a kind of strict scrutiny derived from "the Daily Mail string of newspaper cases," which he proceeded to read as narrowly as possible. ${ }^{399}$ As noted above, Justice Stevens paid very little attention to that line of cases, and barely mentioned strict scrutiny doctrine. Justice Breyer's characterization of a fact-bound balancing came far closer to the essence of the majority opinion.

Chief Justice Rehnquist also took issue with Justice Stevens's rejection of the government's deterrence argument, calling "[r]eliance upon the 'dryup-the-market' theory . . . both logical and eminently reasonable .... .,400 And he emphasized the First Amendment right of Bartnicki and Kane to keep their conversation from the public domain. ${ }^{401}$ Finally, he castigated the Court for relying on the Pentagon Papers case and "other inapposite cases" to subordinate the right to communications privacy "to the claims of those who wish to publish the intercepted conversations of others. ${ }^{, 402}$

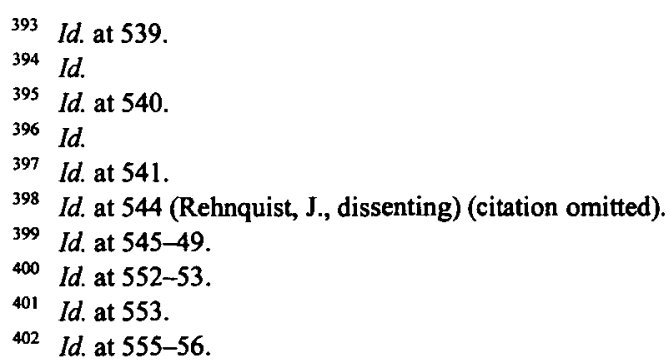




\section{CONCLUSION: A MIXED BLESSING?}

In assessing the impact of Bartnicki on the future development of First Amendment doctrine, one may choose to adopt the expansive reading given the majority opinion by the dissent or the narrow reading given in the concurrence. Ironically, the press would surely favor the former; indeed, they argued all along for strict scrutiny and the invocation of the constitutional privacy cases. The concurring opinion is far more problematic: can one broadcast an intercepted conversation that does not threaten physical harm? Justice Stevens's opinion is so poorly crafted as to leave in doubt not merely the answer, but even the proper analytical approach. ${ }^{403}$

To take one hypothetical "ripped from the headlines" as this Article was being drafted, consider the prospective case against WikiLeaks.com for publishing hundreds of thousands of military and diplomatic documents allegedly downloaded from a government database by a disaffected soldier. ${ }^{404}$ As of this writing, no indictment had been handed up by a grand jury, but assuming arguendo that no one associated with WikiLeaks participated in the unlawful leaking except as beneficiary, there is only one difference between the case against WikiLeaks and the case against Fred Vopper: national security versus personal privacy as the subject matter of the unlawfully acquired information. ${ }^{405}$

Thus, if one reads Bartnicki as imposing strict scrutiny when reviewing any restriction on the dissemination of unlawfully obtained, but publicly important information, where the disseminator did not participate in the unlawful acquisition, then WikiLeaks is home free. On the other hand, if one reads Bartnicki as a case of ad hoc balancing, then the Court will ultimately have to decide whether the freedom to publish without fear of sanction is outweighed in this case by national security, as opposed to personal privacy, considerations.

So far, the lower courts' applications of Bartnicki have not been particularly helpful in that regard. Several cases have distinguished

403 See Rodney A. Smolla, Information as Contraband: The First Amendment and Liability for Trafficking in Speech, 96 Nw. U. L. REV. 1099, 1118 (2002) ("Astonishingly, at no point in Justice Stevens's opinion does the Court come right out and say what standard of review or doctrinal test it is applying to the laws before it.").

${ }_{404}$ See Charlie Savage, U.S. Weighs Prosecution of WikiLeaks Founder, but Legal Scholars Warn of Steep Hurdles, N.Y. TIMES, Dec. 2, 2010, at A18, available at http://www.nytimes.com/2010/12/02/ world/02legal.html.

${ }^{405}$ There are no legally meaningful differences between the website and the radio station as platforms or between Assange and Vopper as communicators, absent Assange's complicity in the unlawful leaking of the information. 
Bartnicki on the ground that the disclosures were not a matter of public concern. ${ }^{406}$ Others have distinguished Bartnicki on the ground that the disseminator participated in the illegal conduct that led to disclosure. ${ }^{407}$ Still others have distinguished Bartnicki where the disclosures involved trade secrets, ${ }^{408}$ copyrights, ${ }^{409}$ or data mining. ${ }^{410}$ In no case reported to date has the holding in Bartnicki been applied to reach a similar conclusion in an analogous case. ${ }^{411}$

The scholarly literature has been rather more enlightening. In his article Information as Contraband, published shortly after the Court issued its opinion in Bartnicki, and clearly inspired by that case, Rodney Smolla saw Bartnicki as an immediate victory for the press, but a longer term victory for privacy interests. ${ }^{412}$ With a majority of Justices (two concurring and three dissenting) accepting an effective intermediate scrutiny standard, ${ }^{413}$ albeit with a "newsworthiness" safety-valve, ${ }^{414}$ Smolla saw the case as

406 See, e.g., Quigley v. Rosenthal, 327 F.3d 1044 (10th Cir. 2003) (distinguishing Bartnicki where intercepted conversations regarding one family's anti-Semitic remarks about another family in the neighborhood were not matters of public concern); Trans Union Corp. v. FTC, 267 F.3d 1138, 1140-41 (D.C. Cir. 2001) (distinguishing Bartnicki where speech at issue-target marketing lists comprising names, addresses, and financial information-involved only matters of private concern); Doe v. Luster, No. B184508, 2007 Cal. App. Unpub. LEXIS 6042, at *15-16 (July 25, 2007) (distinguishing Bartnicki where speech at issue-a videotape of woman being raped-is not a matter of public concern); M.G. v. Time Warner, Inc., 107 Cal. Rptr. 2d 504, 512 (Cal. Ct. App. 2001) (distinguishing Bartnicki where speech at issue — photo of team coached by child molester-was not a matter of public concern).

407 See, e.g., Boehner v. McDermott, 441 F.3d 1010, 1017 (D.C. Cir. 2006), aff'd en banc, 484 F.3d 573 (2007) (defendant's actual knowledge of the circumstances of the illegal interception made this case distinguishable from Bartnicki); Bowens v. Ary, No. 282711, 2009 Mich. App. LEXIS 2000, at *20-21 (Sept. 24, 2009) (distinguishing Bartnicki where the defendant directed the recording of a private conversation without consent); State v. Baron, 769 N.W.2d 34, 48 (2009) (distinguishing Bartnicki where the defendant illegally accessed the email account of a public official to disseminate truthful information about him).

${ }^{408}$ See DVD Copy Control Ass'n v. Bunner, 75 P.3d 1, 15 (Cal. 2003) (Bartnicki inapplicable, by its own terms, where disclosure in question involved trade secrets).

${ }^{409}$ See Barclays Capital, Inc. v. Theflyonthewall.com, 700 F. Supp. 2d 310, 354 n.15 (S.D.N.Y. 2010) (distinguishing Bartnicki where the cause of action is copyright infringement and misappropriation of hot news).

${ }^{410}$ See IMS Health Inc. v. Ayotte, 550 F.3d 42, 51 (1st Cir. 2008) (Bartmicki inapplicable where disclosure and use of personally identifiable information by a data mining company was found to be conduct, not speech).

411 Indeed, in SEC v. Rajaratnam, the court quoted Bartnicki for the proposition that "disclosure of the contents of a private conversation can be an even greater intrusion on privacy than the interception itself." 622 F.3d 159, 169 (2d Cir. 2010) (emphasis added) (quoting Bartnicki v. Vopper, 532 U.S. 514 , $533(2001))$.

${ }^{412}$ Smolla, supra note 403, at 1149-50.

413 Id. at 1119.

414 Id. at 1170. 
elevating personal privacy to an interest of constitutional dimension on a par with freedom of speech and press. ${ }^{415}$

Nevertheless, Smolla drew exactly the opposite conclusion with respect to classified information. Hypothesizing a new "Official Secrets Act" of the kind enacted by Congress to punish journalists for disclosing leaked classified information, and vetoed by President Clinton, ${ }^{416}$ Smolla drew a sharp distinction between the "steal" considered in Bartnicki and the "leak" contemplated by the new law. Quoting both Laurence Tribe ${ }^{417}$ and Potter Stewart, ${ }^{418}$ Smolla asserted that "[r]espect for the structural independence of the media contemplated by the Constitution prohibits courts from conscripting journalists as leak-police. ${ }^{, 419}$ Thus, to Smolla, even the narrowest reading of Bartnicki poses no danger for a Julian Assangeassuming his hands are otherwise clean and WikiLeaks is found to share that "structural independence." $\$ 420$

Of course, the Court has changed since Smolla wrote in 2002 , and so has the temper of the times. It may be that the best that can be said for the Bartnicki decision is that, absent participation in the unlawful acquisition of newsworthy information, the press is as free to publish it as changing societal values will allow. At the very least, the "content-neutral law of general applicability" no longer presents the insurmountable obstacle to First Amendment protection that it was under Cohen v. Cowles Media. ${ }^{421}$ The Landmark-Daily Mail-Florida Star line of cases has emerged none the worse for wear-Chief Justice Rehnquist's crabbed reading garners only three votes. And, most importantly, Fred Vopper and his media allies got the outcome they wanted, if not the mandate, taking the press a small step closer to the ultimate goal of protection for all truthful information of public importance.

415 Id. at 1150 .

416 Id. at $1166-67$

417 Id. at 1167 ("There may be some rough 'law of the jungle' notion at work here: even if no sweeping right to know will be recognized as a limit on government's power to try to keep matters bottled up, an outsider who manages to obtain otherwise confidential information cannot then be prevented from disseminating it-or punished for having done so." (quoting LAURENCE H. TRIBE, AMERICAN CONSTITUTIONAL LAW 965 (2d ed. 1988))).

418 Id. at 1168 ("So far as the Constitution goes, the autonomous press may publish what it knows, and may seek to leam what it can." (quoting Potter Stewart, Or of the Press, 26 HASTINGs L.J. 631,636 (1975))).

419 Id. at 1168 .

420 See id.

421501 U.S. 663 (1991). 